\title{
Promjena politike osiguravanja kvalitete na javnim sveučilištima u Hrvatskoj u periodu od 2001. do 2013. godine
}

\author{
NIKOLA BAKETA \\ Institut za društvena istraživanja, Zagreb
}

\begin{abstract}
Sažetak
Autor u radu iz teorijske perspektive historijskog institucionalizma i koncepta promjene politike detektira i analizira pokretače promjene te ključne uvjete koji su omogućili ili spriječili promjenu politike osiguravanja kvalitete na javnim sveučilištima u Hrvatskoj u periodu od 2001. do 2013. godine. Radom je obuhvaćeno sedam javnih sveučilišta - Sveučilište u Zagrebu, Sveučilište u Splitu, Sveučilište u Rijeci, Sveučilište Josipa Jurja Strossmayera u Osijeku, Sveučilište u Zadru, Sveučilište u Dubrovniku, te Sveučilište Jurja Dobrile u Puli. Koristeći se kvalitativnim metodama (usmjerena analiza sadržaja i polustrukturirani intervjui) kojima se prati proces promjene politike utvrđeno je da su glavni pokretači promjene izvanjski. Glavni zaključak je da institucionalna struktura može biti preduvjet koji omogućuje akterima provedbu promjene, ali da su pojedine karakteristike aktera, poput njihovih kapaciteta, nužne da bi se promjena i dogodila.
\end{abstract}

Ključne riječi: kvaliteta, sveučilište, promjena politike, historijski institucionalizam, Hrvatska

\section{Uvod}

Pojedina politika (policy) ne mora nužno biti javna (public policy), nego može biti i povezana s pojedinom institucijom i njezinim unutrašnjim djelovanjem. ${ }^{1}$ Primjer takvih politika su one unutar sveučilišta o kojima će biti riječ u ovom radu. Naime, sveučilišta imaju određeni stupanj autonomije u svom djelovanju te sukladno tome

${ }^{1}$ Rad je nastao na temelju doktorske disertacije Komparativna analiza promjena politika visokog obrazovanja na javnim sveučilištima u Hrvatskoj od 2001. do 2013. godine. Mentor doktorskog rada bio je Tihomir Žiljak. 
kreiraju politike i razvoj. U pristupu takvim politikama treba uzeti u obzir način funkcioniranja i institucionalnu strukturu organizacije čije se politike promatraju. Cilj rada je detektirati ključne uvjete koji su omogućili odnosno spriječili promjenu politike osiguravanja kvalitete (OK) na sedam javnih sveučilišta u Hrvatskoj u periodu od 2001. do 2013. godine. Tih sedam sveučilišta su: Sveučilište u Zagrebu (UNIZG), Sveučilište u Splitu (UNIST), Sveučilište u Rijeci (UNIRI), Sveučilište Josipa Jurja Strossmayera u Osijeku (UNIOS), Sveučilište u Zadru (UNIZD), Sveučilište u Dubrovniku (UNIDU) i Sveučilište Jurja Dobrile u Puli (UNIPU). Period od 2001. do 2013. godine se uzima stoga što je Hrvatska 2001. potpisala Bolonjsku deklaraciju, a 2013. ušla u EU, ali i zbog potrebnog vremenskog odmaka. Naime, Sabatier (1999) tvrdi da je potreban minimum od deset godina kako bi promjena bila vidljiva. S druge strane, u potpunosti imajući na umu da je Bolonjski proces širi od politika EU u području obrazovanja, treba istaknuti da pojedini autori (Capano i Piattoni, 2011) prepoznaju preplitanje aktivnosti i govore o lisabonizaciji Bolonjskog procesa, a inkorporaciju Lisabonskog procesa u Bolonjski ističu i Dobbins i Knill (2014). Stoga je opravdano uzeti završetak procesa pristupanja Hrvatske EU-u kao krajnju točku ovog istraživanja.

\section{Promjena politike i historijski institucionalizam}

Pojam policy ima različite definicije, a rasprava o tome je detaljnije predstavljena $u$ knjizi The Public Policy Process (Hill, 2005: 6-10). U ovom radu smatram primjerenim koristiti onu koju iznosi Jenkins (prema ibid.: 7), koji pod tim pojmom misli na "skup povezanih odluka... koje se odnose na odabir ciljeva i sredstava za njihovo ostvarivanje u specificiranim situacijama...", međutim ne smije se zaboraviti ni aspekt neodlučivanja, tj. otpor promjeni koji uvodi Smith (prema ibid.). Promjena politike (policy change) je iznimno kompleksan i složen proces "koji obuhvaća sve aspekte transformacije, preoblikovanja, odnosno (ne)stabilnosti neke politike" (Petek, 2014: 137). Shodno tome u ovome radu ću promatrati odluke i poteškoće (prepreke) u promjeni politike OK na javnim sveučilištima u Hrvatskoj s namjerom utvrđivanja ključnih uvjeta koji su omogućili odnosno spriječili promjenu navedene politike.

Treba istaknuti da se promjena politike odvija unutar određenog institucionalnog okvira te je osnovna pretpostavka da će upravo taj okvir imati važnu ulogu u promjeni politike. Pod institucionalnim okvirom misli se na ustrojstvo sveučilišta s obzirom na njegovu integriranost. Dodatno pojašnjenje integracije sveučilišta nalazi se u dijelu koji razmatra povijesni razvoj javnih sveučilišta u Hrvatskoj. S druge strane, sveučilišta sudjeluju u procesu promjene kao organizacijski akter. ${ }^{2}$

2 "U ovoj studiji naglasak je na institucijama koje se smatraju temeljnim pravilima igre, a fokus na organizacijama (i njihovim dionicima) prvenstveno je u vidu njihovih uloga kao agenata institucionalne promjene; dakle naglasak je na interakciji institucija i organizacija" (North, 1990: 5). 
Važnost $i$ teorijsku složenost istraživanja promjene politike $u$ različitim aspektima je razmatrao niz autora (Howlett i Cashore, 2009; Rayner, 2009; Real-Dato, 2009), a strukturiran pregled glavnih teorijskih i epistemoloških pitanja povezanih s promjenom politike izložio je Giliberto Capano (2009). Razmatrajući ta pitanja, Capano iznosi glavna pitanja koja se javljaju u tom području. Tako se postavljaju pitanja linearnosti ili nelinearnosti procesa promjene, evolucijskog ili revolucijskog razvoja promjene, pokretača promjene, razmatra se pitanje što čini objekt promjene, zatim koji se tip promjene politike (inkrementalni ili radikalni) događa, pitanje ireverzibilnosti i reverzibilnosti ishoda promjene, pitanje nivoa apstrakcije i s tim povezana dilema struktura/akter, te se u konačnici bavi uzročnim mehanizmima.

S obzirom na fokus ovog rada, ovdje ću se osvrnuti na pokretače promjene, nivo apstrakcije i dilemu struktura/akter. Po pitanju pokretača izdvojeni su endogeni i egzogeni uzroci ( ibid.; Mahoney i Thelen, 2010). Među egzogene uzroke ubrajaju se vanjski šokovi (npr. ekonomska kriza), javno mnijenje, prirodne katastrofe (Birkland, 2006: 4, navodi uragane, tsunamije, potrese), a vanjskim utjecajima mogu se smatrati i procesi i inicijative koji dolaze s međunarodne razine, dok se među endogene ubrajaju alati, vrijednosti, strategije, ideje, kapaciteti aktera (Capano, 2009: 23).

Capano (2009) smatra potrebnim odrediti promatra li se makronivo politike u kojem je promjena politike rezultat spomenutih makrofaktora (političko natjecanje, ekonomski uvjeti i javno mnijenje) ili mikronivo koji uključuje detaljnu analizu i rekonstrukciju određenog razvoja politike na nižim razinama. Treba odrediti i odnos strukture i aktera djelovanja, odnosno izbjegavati oslanjanje samo na jedan aspekt. Strukturalizam stavlja veći naglasak na strukturu i zanemaruje ulogu aktera, a s druge strane krajnja neovisnost aktera koja sve prepušta slučaju smanjuje mogućnost predviđanja procesa. Konačno, Capano (ibid.) razmatra uzročne mehanizme i varijable. Ističe kako je moguće uspostaviti pozitivističku logiku, koja je linearna; u njoj postoji jasna odvojenost nezavisnih i zavisnih varijabli i pomoću nje nastoji se odgovoriti na pitanje zašto se nešto dogodilo. S druge strane, moguće je usmjeravanje na niz uzročnih uvjeta koji dovode do specifičnog ishoda. U tom slučaju treba identificirati tu kombinaciju uvjeta "i kada se ta kombinacija identificira, moguće je specificirati kontekst koji omogućuje ili onemogućuje specifične individualne uzroke" (Ragin, 2006: 640) te se nastoji odgovoriti na pitanje kako se promjena dogodila.

Promjena politike se u ovom slučaju razmatra u okviru historijskog institucionalizma. Taj teorijski okvir definira institucije kao "formalne i neformalne procedure, rutine, norme i konvencije ugrađene u organizacijsku strukturu političkog sustava" (Hall i Taylor, 1996: 938). Tako definirane institucije predstavljaju okvire unutar kojih djeluju akteri. Ti akteri su u svom djelovanju ograničeni pojedinim pri- 
jašnjim događajima u povijesnom razvoju institucije. Važnost utjecaja institucija, njihove postojanosti i različitog ustroja na aktere je zastupljena u nizu istraživanja povezanih s javnim politikama, što se, primjerice, može vidjeti kod Steinmoa (2008). Glavna pitanja na koja autori takvog pristupa nastoje odgovoriti jesu: zašto je određeni izbor uopće napravljen, zašto su se pojavili određeni ishodi i kako institucije oblikuju ponašanje aktera. Značajke koje izdvajaju Immergut (1998) i Hay (2006) važne su za shvaćanje osnovnih polazišta historijskog institucionalizma. Prema Immergut (1998: 18), interesi aktera unutar historijskog institucionalizma oblikovani su djelovanjem institucija, a kroz njih se očituje i povijesni razvoj institucija u kojima djeluju. Nadalje, samoreflektivnost je bitna značajka aktera koji u svom djelovanju uzimaju u obzir društvene, kulturne i povijesne norme, a politički proces je strukturiran kroz ustave, državne strukture, političke institucije, mreže javnih politika i grupne odnose. Unutar takvog sustava moć ovisi o prepoznavanju od države, pristupu odlučivanju i sličnim faktorima. Također, Hay (2006: 56-57) smatra da historijski institucionalisti $u$ istraživanjima pristupaju interpretaciji stvarnosti tako da nastoje kontekstualizirati aktere unutar povijesnog $\mathrm{i}$ institucionalnog okruženja, a zatim koriste taj povijesni razvoj i vremenske sekvence kako bi izvodili zaključke i objasnili procese. Pri tome se često koriste metodom narativa, gustih opisa ili historijskom metodom.

Nadalje, vremenska dimenzija ima važnu ulogu u objašnjavanju fenomena u historijskom institucionalizmu. Tako treba istaknuti da se historijski institucionalizam razlikuje od pukog bilježenja pojedinih povijesnih događaja ili činjenica koje su se dogodile. Znači, istraživanje historijskih institucionalista "ne gleda samo na prošlost, nego na procese koji se odvijaju tijekom vremena" (Pierson i Skocpol, 2002: 698). Odabiri unutar pojedine politike u historijskom razvoju institucija i prijeđeni put određuju moguća policy rješenja u budućnosti. Imajući to na umu, moguće je fokusirati se na poimanje uzročnosti u historijskom institucionalizmu. Tako Stinchcombe (1968), ističući povijesnu i temporalnu dimenziju istraživanja, vrstu uzročnosti koja se primjenjuje u takvom pristupu naziva historijskom uzročnosti. Naime, zbog različitog konteksta i aktera koji uče na temelju povijesnih događaja u različitim vremenskim periodima, nije moguće na temelju istih varijabli donositi zaključke o istovrsnim ishodima (Immergut, 1998; Steinmo, 2008). Paul Pierson (2004) posebno se bavi vremenskom dimenzijom u svojoj knjizi Politics in Time: History, Institutions and Social Analysis. Ondje se usredotočuje na specifičniju ulogu vremenskih sekvenci - na to kako se pojedini događaji razvijaju tijekom vremena, preklapaju i dovode do promjena. U suštini, ideja je "povezivanje odvojenih elemenata ili dimenzija politike tijekom vremena. Ako se dva događaja ili određena procesa javljaju $u$ istom povijesnom trenutku, rezultat može biti različitiji nego kada su oni vremenski odvojeni” (Pierson, 2004: 55). Shodno tome, 
stav unutar historijskog institucionalizma, koji jasno izražavaju Pierson i Skocpol (2002: 699), jest da treba isticati važnost teorijskog povezivanja varijabli i sustavnog praćenja procesa koji se dogodio. Takav pristup političkom procesu, analizi i uzročnosti jasno ukazuje na razlikovanje historijskog institucionalizma u odnosu na institucionalizam racionalnog izbora. Tako Hall i Taylor (1996: 942) primjećuju da historijski institucionalisti "smatraju svijet mnogo kompleksnijim nego što je to svijet sklonosti i institucija kakvim ga vide institucionalisti racionalnog izbora." Isto tako treba istaknuti činjenicu da "historijski institucionalisti uglavnom ne proučavaju samo jednu instituciju ili proces u zadanoj točki vremena, nego u većoj mjeri nastoje gledati na politiku kao na iznimno složen sklop procesa i institucija koji variraju tijekom vremena i ulaze $u$ interakciju na zanimljive i neočekivane načine" (Miller, 2010: 26). Naravno, takav pristup ima ograničenu mogućnost predviđanja te je zapravo više usmjeren na neku vrstu objašnjavanja. Međutim, sama epistemološka pozicija historijskog institucionalizma ne ostavlja mogućnost predviđanja jer smatra da, zbog spomenute kompleksnosti i međuovisnosti varijabli, predviđanje i nije moguće. Upravo zbog toga se više smatra deskriptivnim nego prognostičkim pristupom (Peters, 1999; Steinmo, 2008; Sanders, 2006).

Različitost korisnosti i primjenjivosti u bavljenju javnim politikama očituje se u radovima Petersa, Pierrea i Kinga (2005) koji koriste historijski institucionalizam kako bi objasnili povratak programa potpora u zamjenu za rad (tzv. workfare) i njihov razvoj u Danskoj, SAD-u i Velikoj Britaniji, reformu javne uprave u Velikoj Britaniji i zemljama Commonwealtha te prijelaz s kejnzijanizma na monetarizam u zapadnim zemljama. Nadalje, Reich (2000) vidi historijski institucionalizam kao prikladan teorijski pristup za proučavanje redistributivnih javnih politika, a Pierson i Skocpol (2002) primjenjuju isti pristup na konkretnu politiku - politiku mirovinskih sustava. Nadalje, Pierson (1996) se služi historijskim institucionalizmom kako bi objasnio integracijske politike Europske unije, a na njegov se rad nastavlja i Bulmer (2009). Osim toga, primjenjivao se i na posebne javne politike u Sjedinjenim Američkim Državama, pa tako Howard (1997) radi na poreznoj i socijalnoj politici, a Gottschalk (2000) na politikama prema radnicima, poslovnoj i zdravstvenoj politici. Iz tog niza navedenih sektorskih politika očigledna je raznolika primjenjivost $\mathrm{i}$ korisnost pristupa $u$ različitim javnim politikama te na različitim razinama analize.

Unutar novog institucionalizma postoji i škola institucionalizma racionalnog izbora koja stavlja veći naglasak na aktere i njihove karakteristike u odnosu na institucije. Naime, institucije služe da bi osigurale pravila i poticaje za usmjeravanje ponašanja racionalnih aktera, odnosno one su "sustav pravila i poticaja" (Rhodes et al., 2006: xiii). Akteri koji djeluju unutar tih institucija nastoje maksimizirati svoju korist, imaju fiksirane preferencije i ponašaju se instrumentalno (Hall i Taylor, 
1996: 944-945) te, kako navodi Peters (1999: 44), imaju "egoistične karakteristike ponašanja", a "osnovni argument pristupa racionalnog izbora je da maksimalizacija korisnosti može i hoće ostati primarna motivacija pojedinaca". Isti autor navodi i tri glavne značajke pristupa institucionalizma racionalnog izbora - jedinstven set pretpostavki (odnosi se na pravila, poticaje i zabrane koji služe racionalnim akterima kao smjernice za djelovanje), jedinstven set problema (problemi kolektivnog odlučivanja) i tabula rasa po pitanju povijesnog razvoja institucija (povijesni razvoj institucija prema njemu ne igra važnu ulogu, nego se promjenom pravila dolazi do promjene ponašanja aktera i njihovih interesa). Posebni problemi za taj pristup javljaju se zbog toga što se svako djelovanje aktera može okarakterizirati kao racionalno te što zbog izrade modela koji objašnjavaju djelovanje dolazi do pretjeranog pojednostavljivanja stvarnosti (ibid.: 43-61; Miller, 2010: 25). Tako Shepsle (2006: 32) tvrdi da je "istraživački program institucionalizma racionalnog izbora temeljen na apstrakciji, pojednostavljenju, analitičkoj strogosti i inzistiranju na čistim linijama analize od osnovnih aksioma preko analitičkih propozicija do empirijskih implikacija”. To u konačnici, prema Shepsleu (2006), znači da samopostavljene granice najviše ograničavaju teoretičare institucionalizma racionalnog izbora. Teoretičari te škole se u svojim istraživanjima uglavnom fokusiraju na javnu upravu i zakonodavna tijela. U okviru grane javnih politika taj pristup značajnu pozornost dobio je u vezi s pitanjima utjecaja Europske unije na države članice (Börzel i Risse, 2000), a zatim i kod interakcije veto aktera i maksimiziranja strategija kao polaznih točaka u objašnjenju promjene politike te objašnjenju koje poticaje za promjenu vidi u eksternim šokovima (Zohlnhöfer, 2009). Isto tako moguće je istaknuti Scharpfa (1997), značajnog predstavnika institucionalizma u čijem su središnjem fokusu akteri (actor-centred institutionalism). Tako on smatra da su javne politike prvenstveno rezultat interakcije aktera i njihovih policy odabira, dok su institucionalni uvjeti koncipirani kao daljnji uzročnici (Scharpf, 2000: 764). Iako ti pristupi i okviri ne zanemaruju strukture unutar kojih akteri djeluju, ipak stavljaju znatno manji naglasak na njih i više se usmjeravaju na aktere.

Važan uvid u razlikovanje škola unutar pristupa novog institucionalizma daje i Colin Hay (2006: 56-57), koji navodi glavne značajke s obzirom na teorijski pristup, pretpostavke, analitički pristup, metode, viđenje institucija, institucionalnu promjenu, ključne teme i slabosti tih škola. Iako između tih škola postoje sličnosti, poput naglaska na institucije i viđenja kako institucije osiguravaju određene pravilnosti i predvidljivost te da su one nastale kao namjeravani produkt aktera (Peters, 1999: 141-145), postoje i jasne razlike u njihovom pogledu na aktere, način njihovog djelovanja, institucije te odnose između institucija i aktera. Upravo različite osnovne postavke koje proizlaze iz korijena pristupa, npr. tabula rasa po pitanju institucija kod institucionalizma racionalnog izbora u odnosu na naglašavanje pri- 
jeđenog puta kod historijskog institucionalizma ili racionalnost i težnja maksimizaciji interesa aktera kod institucionalizma racionalnog izbora u odnosu na važnost identiteta aktera, vrijednosti i kolektivistički pristup kod sociološkog institucionalizma, pokazuju da postoje i fundamentalne razlike među njima. Tako Peters (ibid.: 145-149) napominje da se škole novog institucionalizma razlikuju s obzirom na definiciju institucija, pogleda na preferencije, koncepcije promjene i odnos aktera $i$ institucija.

Za potrebe ovog rada služit ću se teorijskim pretpostavkama historijskog institucionalizma. Razlog tomu je važnost takvog pristupa za objašnjenje izbora u procesu oblikovanja i provedbe javnih politika, uzimanju u obzir formalnih i neformalnih institucionalnih uređenja te važnosti temporalne dimenzije koja omogućuje uvid u provedbu javnih politika kroz vrijeme (Peters, Pierre i King, 2005). Jedno od važnih pitanja u sklopu historijskog institucionalizma je odnos strukture i aktera. Naime, pretpostavlja se da su ograničenja institucionalnog uređenja usvojena od aktera te da oni djeluju u skladu s njima. Iako postoji jasna veza, odnosno smjer utjecaja od institucije prema akterima, još uvijek nije u potpunosti jasno na koji način akteri oblikuju i utječu na institucije. Stoga treba raditi na tzv. rješenju problema odnosa strukture i aktera kako bi se teorijski jasnije povezivali rezultati, procesi i akteri. $U$ tom pogledu treba istaknuti da bi dodatno razrađivanje uloge aktera u donošenju odluka i aktivnosti unutar institucija omogućilo više eksplanatorne moći i unijelo inherentnu logiku u historijski institucionalizam (ibid.: 1284). Upravo će stavljanje dodatnog naglaska na ulogu organizacijskih aktera unutar historijskog institucionalizma biti jedan od fokusa ovog rada.

\section{Metodologija}

S metodološke strane odabrana je kvalitativna metodologija. Samo praćenje procesa promjene politika zahtijeva uvid u cjelokupni tijek procesa, a to nije moguće ostvariti ako se gledaju samo pojedini segmenti na kraju vremenskih razdoblja izraženi kvantitativnim pokazateljima. Nadalje, u području visokog obrazovanja u Hrvatskoj te na sveučilištima nije postojalo sustavno prikupljanje podataka o provedbi pojedinih politika, što onemogućuje komparaciju kvantitativnih pokazatelja. Zato se koristi kombinacija kvalitativnih metoda koja uključuje kvalitativnu analizu sadržaja, polustrukturirane intervjue s ekspertima iz područja visokog obrazovanja te sekundarne izvore podataka. Kvalitativnom analizom sadržaja smatra se "istraživačka metoda za subjektivnu interpretaciju sadržaja tekstualnih podataka kroz sustavnu klasifikaciju procesa kodiranja i identificiranja tema" (Hsieh i Shannon, 2005: 1278). Kao jedan od pristupa u okviru analize sadržaja, navedeni autori izdvajaju usmjerenu analizu sadržaja. Istraživači u tom pristupu kreću od postojeće teorije i prethodnih istraživanja, ali s namjerom nadopune i nadogradnje teorijskog 
okvira i koncepta. Međutim, isto tako ostavlja se opcija prepoznavanja novih kategorija i kodova koji se pokazuju kao relevantni u istraživanju. Upravo novi uvidi služe kako bi se unaprijedilo postojeće znanje u području istraživanja ili za davanje novog pogleda na istraživani fenomen. "Glavna snaga usmjerenog pristupa analizi sadržaja jest da postojeće teorije mogu biti podržane i proširene. Osim toga, kako istraživanje nekog područja raste, usmjereni pristup jasno pokazuje da u stvarnosti istraživači vrlo vjerojatno neće polaziti od nekritičke perspektive koja se često promatra kao obilježje prirodnjačkih nacrta" (ibid.: 1283). Kvalitativna analiza sadržaja obuhvaća nekoliko razina. Njome su obuhvaćeni zapisnici sjednica senata sveučilišta u promatranom razdoblju, dostupni strateški dokumenti sveučilišta te intervjui s relevantnim akterima iz tiska. Intervjui iz tiska su prikupljeni uz pomoć agencije Presscut i njezinih resursa te je pronađeno 510 intervjua i tekstova povezanih s glavnim akterima u visokom obrazovanju. Pri provedbi kvalitativne analize sadržaja korišten je kompjuterski program NVivo 10 te su pomoću njega obrađivani prikupljeni dokumenti. Podaci su kodirani za svako posebno sveučilište te specifičnu politiku - mobilnost, socijalna dimenzija, upisna politika, školarine, struktura i kurikulum te posljednje osiguravanje kvalitete, što će biti i tema ovog rada. Osim samog kodiranja prema sveučilištu i pojedinoj politici, kodiranje je rađeno i prema mjesecu i godini rasprave. Razlog za to leži u specifičnosti praćenja procesa tijekom vremena (od početka do kraja promatranog razdoblja). Za potrebe replikacije i provjere vjerodostojnosti analize bilo bi npr. potrebno uzeti zapisnike sjednica Senata Sveučilišta u Zagrebu te kronološki detektirati diskusije koje se odnose na temu osiguravanja kvalitete, a zatim praćenjem procesa utvrditi razloge (ne)donošenja pojedinih odluka, ali i vremenski period potreban za ispunjavanje zacrtanih ciljeva te vremenske točke u kojima su ti ciljevi ostvarivani. S obzirom na to da se radi o kvalitativnoj analizi sadržaja, zahtijeva se praćenje razvoja, a ne kvantificiranje pojavnosti neke teme. Sam kvantitativni pokazatelj frekventnosti pojavljivanja neke teme ne bi dao odgovor o razlozima (ne)donošenja odluke.

Kvalitativni intervju važan je zbog toga što omogućuje dublje razumijevanje određenog fenomena. Postoje različiti pogledi i definicije istraživačkog intervjua, ali većina se svodi na to da je istraživački intervju kvalitativna metoda kojom je moguće prikupiti informacije koje nisu vidljive na druge načine - subjektivne točke viđenja, životne povijesti, događaji koji nisu (u potpunosti) dokumentirani, kompleksni procesi koji su samo djelomično dokumentirani, različiti diskursi. Stoga intervjui omogućuju kreiranje detaljnije slike o slučajevima i istraživačkim problemima za koje smo zainteresirani (Richards, 1996). Održano je devet polustrukturiranih intervjua (Berg, 2001; Myers i Newman, 2007) s ekspertima iz područja visokog obrazovanja oko prethodno spomenutih tema u razdoblju od 15. travnja do 13 . svibnja 2016. godine. Svi sudionici su potpisali suglasnost o sudjelovanju kojima im se jamči anonimnost te nekorištenje informacija koje bi mogle dovesti do identi- 
fikacije sudionika. Svim sudionicima je nakon održanih intervjua poslan transkript te su mogli ukazati na potencijalne pogreške ili informacije za koje smatraju da ne trebaju biti objavljene, a koje bi mogle otkriti njihov identitet. Na temelju njihovih uvida nastoji se dobiti informacije koje su nedostupne na osnovi dokumenata i zahtijevaju posebna znanja te se nastoje razjasniti potencijalne nedoumice koje se javljaju. Vodeće osobe sa sveučilišta ili pojedinih institucija nisu uključene jer je u promatranom vremenu došlo do više promjena vodećih ljudi tih institucija te bi bilo iznimno teško obuhvatiti sve bitne aktere i javlja se pitanje njihove objektivnosti.

Glavni dio analize politike OK pojedinog sveučilišta temeljen je na zapisnicima sjednica senata te upotpunjen drugim dokumentima koji su navedeni, izjavama čelnika u novinama koje su navedene te potkrijepljene izjavama stručnjaka prikupljenima u kvalitativnim intervjuima koje su također izdvojene i navedene.

\section{Povijesni pregled i (ne)integriranost sveučilišta}

UNIZG razvijao se kroz nekoliko faza od 1669. godine kad je osnovana Neoacademia Zagrabiensis. Nakon 1776. godine kontrolu preuzima država odlukom Marije Terezije te je uspostavljena Kraljevska akademija znanosti (Samolovčev, 1989). Stotinjak godina kasnije, točnije 1874. godine, osnovano je Sveučilište u Zagrebu i u njegovom su sklopu bili Teološki, Filozofski i Pravni fakultet. ${ }^{3}$ Prema Samolovčevu (ibid.), u razdoblju ekspanzije visokog obrazovanja i transformacije visokog obrazovanja od 1954. do 1982. godine osnovana su još tri sveučilišta na području današnje Republike Hrvatske, to su sveučilišta u Splitu, Rijeci i Osijeku. Sva tri osnovana su 1970-ih godina te je tada došlo i do jasne uspostave pravne osobnosti fakulteta u odnosu na sveučilišta. Isti autor navodi da su "federalni ustav iz 1963. godine i republički ustavi uspostavili fakultete i više škole kao autonomne i samoupravljačke organizacije posebnog društvenog interesa. Iako ne s posebnim ovlastima, sveučilišta su u praksi ostala obvezna udruženja fakulteta i viših škola" (ibid.: 31).

I Juroš (2006) navodi da je sveučilištima tijekom 1970-ih principom samoupravljanja oduzeta stvarna moć odlučivanja; tu moć preuzele su sastavnice, koje su dobile pravnu osobnost. Tako su krajem 1980-ih u Hrvatskoj postojala spomenuta četiri sveučilišta te su ona bila više neobvezan skup fakulteta nego institucije koje imaju upravljački karakter. Iz tog razloga Marentič-Požarnik, Lapajne i Mihevc (1989: 63) opisuju fakultete kao:

Visokoškolske ustanove koje su samoupravne jedinice sveučilišta. Na primjer, fakultet se može sastojati od više takvih institucija. Svaka od njih ima vijeće za upravljanje svojim poslovima [...] Sveučilište je više ili manje labava udruga fakulteta i drugih institucija. Ono koordinira postupke prijama, zajedničke temeljne

${ }^{3}$ http://www.unizg.hr/o-sveucilistu/sveuciliste-jucer-danas-sutra/povijest-sveucilista/ 
nastavne planove i međunarodne kontakte svojih članova; izdaje diplome, potvrde i nagrade izvrsnim studentima.

Prikaz povijesnog razvoja i strukture tih sveučilišta može se pronaći i u radovima Uvalića (1952), Potkonjaka (1989), Šoljana (1991) te Mandića (1992). Davanje autonomije fakultetima usmjerilo je daljnji razvoj sveučilišta na način da su fakulteti zadržali pravnu osobnost, te upravljačke strukture sveučilišta zapravo nisu imale stvarnu mogućnost upravljanja i kontrole nad sastavnicama. U slučaju UNIZG-a uz takvo je zakonsko rješenje dodatan faktor bila i veličina, odnosno veći broj sastavnica. Naravno, sam proces nastanka tih četiriju sveučilišta bio je takav da su prvo osnovani pojedini fakulteti ili su oni nastali na temelju viših škola te su se tijekom vremena povezali i osnovali sveučilišta kao nadsvođujuće institucije. Takav povijesni razvoj, od dna prema vrhu, zasigurno je utjecao na razvoj zasebnih identiteta pojedinih sastavnica te je dobio i dodatnu pravnu osnovu kroz spomenuta ustavna rješenja.

Posljednja tri sveučilišta osnovana su u razdoblju od 2002. do 2006. godine i na njima ne postoji pravna osobnost pojedinih sastavnica. Ustrojena su po odjelskom principu i sastavnice su pod jasnom upravom sveučilišta. Prvo je osnovano Sveučilište u Zadru. Osnova razvoja UNIZD-a ${ }^{4}(2018)$ bio je Filozofski fakultet koji je osnovan u suradnji s UNIZG-om 1956. godine, a ušao je u sastav UNIST-a 1974. godine, gdje je i ostao sve do 2003. kada je osnovan UNIZD. Kasnije iste godine osnovan je i UNIDU (2018). Sveučilište je nastalo na temelju Pomorskog fakulteta i Fakulteta za turizam i vanjsku trgovinu, a oba su od 1976. godine bila dio UNIST-a. Međutim, 1996. godine dolazi do izdvajanja iz UNIST-a i osnivanja prvog javnog veleučilišta u Hrvatskoj. Ono se održalo do 2003. godine kada je transformirano u sveučilište. Konačno, posljednje osnovano sveučilište je UNIPU (2018). Ono se temelji na Višoj ekonomskoj školi i Pedagoškoj akademiji koje su osnovane početkom 1960-ih te su kasnije prerasle u Fakultet ekonomije i turizma te Filozofski fakultet i Visoku učiteljsku školu. Sve do 2006. godine kada je osnovan UNIPU te su sastavnice bile dio UNIRI-a.

Starija sveučilišta (UNIZG, UNIST, UNIOS i UNIRI) kao sastavnice imaju većinom fakultete, a novija sveučilišta (UNIZD, UNIDU i UNIPU) su odjelskog tipa, s izuzetkom UNIPU-a koji ima podijeljenu strukturu. Trend prelaska odjela u fakultete na UNIPU-u javlja se krajem promatranog razdoblja te upućuje na smanjenu integraciju UNIPU-a. Osim toga, način odlučivanja na sveučilištima pokazuje jesu li postojala pitanja o kojima su sastavnice donosile odluke u suprotnosti s odlukama senata (npr. kod upisne politike koja je u ovlasti senata, ali često ga se zaobilazilo; pogledati dio o upisnoj politici) te je li postojalo suprotstavljanje integraciji. Na toj osnovi vidljivo je da i unatoč formalnopravnom određenju postoje razlike između sveučilišta

${ }^{4}$ http://www.unizd.hr/Onama/tabid/55/language/hr-HR/Default.aspx 
koja imaju iste statuse sastavnica. Tako UNIZG, UNIST i UNIOS pokazuju klasično funkcioniranje u kojem pravna osobnost sastavnica dolazi do izražaja, česta su razilaženja u djelovanju na razini sveučilišta i sastavnice (npr. neusklađivanje strateškog djelovanja) te zaobilaženje odluka senata (npr. u slučaju upisnih kvota).

Iako je formalno neintegriran, na UNIRI-u se primjećuju aspekti integracije i stvarnog upravljanja s razine sveučilišta. Tako se 2001./2002. bilježi utjecaj na smanjivanje kvota pojedinim sastavnicama, a zatim je odlučeno i da natječaj za upis bude zajednički te da se Sveučilište prezentira kao integralna cjelina. Također, nakon donošenja zakona 2003. godine kojim se uređuje funkcionalna integracija na UNIRI-u je zaključeno da pravna osobnost sastavnica ne smije priječiti integraciju te da je spremnost akademske zajednice ključna za taj korak, a supsidijarnost kroz pravnu osobnost može doprinijeti funkcioniranju. Usto, samo UNIRI se u pojedinim dokumentima izjašnjava kao poluintegrirano sveučilište (UNIRI, 2012).

Kod preostala tri sveučilišta vidljiva je integriranost u odlučivanju koja proizlazi iz pravnog ustroja tih sveučilišta. Međutim, UNIPU je djelomično odstupio od toga. Tako je pri donošenju Statuta 2007. godine istaknuto da je povećana nadležnost vijeća odjela te ostavljena mogućnost i daljnjeg prijenosa nadležnosti na njih. Nadalje, 2011. godine postavljen je i zahtjev za povratkom statusa fakulteta te je donesena odluka da vraćanje pravne osobnosti nije moguće prema trenutnoj zakonskoj regulativi. Međutim, od 2013. godine pojedini odjeli mijenjaju naziv i postaju fakulteti iako ne postoji formalna promjena statusa, $\mathrm{tj}$. vraćanje pravne osobnosti, ali je došlo do prebacivanja dijela ovlasti na fakultete koje nemaju odjeli. Tako se UNIPU, unatoč pravnom određenju, zbog svojih praksi također može smatrati poluintegriranim sveučilištem, a UNIZD i UNIDU integriranim sveučilištima.

\section{Razvoj sustava OK u Hrvatskoj}

Sustavni pristup OK se u Hrvatskoj počinje razvijati nakon 2009. godine. Naime, prije donošenja Zakona o osiguravanju kvalitete u znanosti i visokom obrazovanju to pitanje nije bilo konkretno i jasno regulirano. Prema Zakonu o visokim učilištima iz 1993. godine za pitanja OK bilo je zaduženo Nacionalno vijeće za visoku naobrazbu (NVVN), a stručna povjerenstva Ministarstva za postupke vrednovanja. U konačnici je NVVN na temelju prosudbe preporučivao Ministarstvu izdavanje vjerodostojnice, pisma očekivanja ili uskraćivanje vjerodostojnice. Takvo zakonsko rješenje ostalo je i u Zakonu o visokim učilištima iz 1996. godine. Nepostojanje sustavnosti do 2009. potvrđuju i stručnjaci u intervjuima:

nisu bile jasno stvorene te petlje, jasno dane odgovornosti, što se uvođenjem sustava osiguranja kvalitete zapravo napravilo stvaranjem određenih dokumenata koji su propisivali određene procese osiguravanja kvalitete $u$ visokom obrazovanju. (Stručnjak 1) 
A prije toga, kažem vam, bilo je više stihijski, stihijski i nekoherentno. Ali ne možemo reći da nije ništa postojalo. Govorimo o toj internoj kulturi kvalitete kakva je bila, nije bilo tih strateških dokumenata, kvaliteta studijskih programa, postojale su ankete studenata, postojali su pojedini mehanizmi, ali to nije bilo. (Stručnjak 3)

Zakonom o znanstvenoj djelatnosti i visokom obrazovanju iz 2003. godine uspostavljeno je Nacionalno vijeće za visoko obrazovanje te ono ministru predlaže kriterije za vrednovanje visokih učilišta i studijskih programa, provodi njihovo vrednovanje, predlaže ministru izdavanje dopusnica i brine za razvitak kvalitete. Zakon je predvidio i osnivanje Agencije za znanost i visoko obrazovanje (AZVO) zadužene za provedbu stručnih poslova pri vrednovanju znanstvene djelatnosti i visokog obrazovanja, osnivanje nacionalne mreže za osiguravanje kvalitete visokog obrazovanja te vrednovanje sustava za unapređenje i kontrolu kvalitete koji se uspostavljaju na visokim učilištima. Havranek, Dodiković-Jurković i Petrović (2013) ističu da su postojali određeni problemi u provedbi unutarnjih sustava OK na visokoškolskim institucijama te navode kako su prema Zakonu o znanosti i visokom obrazovanju obvezu ustroja sustava kvalitete imala visoka učilišta u sastavu sveučilišta, ali ne i veleučilišta i visoke škole. Smatraju da "proces ustroja nije uspješno proveden radi otpora dionika i neprepoznavanja vrijednosti uvođenja sustava kvalitete" (ibid.: 246), a ističu i kako je Ministarstvo 2005. godine definiralo uspostavu sustava jamstva kvalitete $u$ sustavu visokog obrazovanja s rokom do kraja 2006. godine. Međutim, tek donošenjem Zakona o osiguravanju kvalitete AZVO je u potpunosti preuzeo brigu o vrednovanju i sustavu OK. Zakon propisuje da se vanjski sustav osiguravanja i unapređivanja kvalitete temelji na nacionalnim, europskim i međunarodnim standardima, a unutarnji sustav svaka ustanova u sustavu znanosti i visokog obrazovanja uređuje svojim općim aktom. Tim Zakonom su sva visoka učilišta obvezana na ustrojavanje jedinica za OK.

Istraživanja sustavâ OK uglavnom su ograničena na pojedina sveučilišta ili segmente sustava (mogu se izdvojiti radovi Buljan Barbača i Gojak, 2011; Lončar-Vicković, Holjenko, Trampus i Dolaček-Alduk, 2011; Ćubela Adorić i Đurđević, 2012; Proroković i Tomić-Koludrović, 2011; Dodiković-Jurković et al., 2014; te Havranek, Dodiković-Jurković i Petrović, 2013). Posljednja dva rada donose posebice korisne informacije o procjeni sustava OK na sveučilištima i temelje se na podacima AZVO-a.

Vanjska vrednovanja sustava OK na javnim sveučilištima provedena su u periodu od 2011. do 2013. Prvo sveučilište bilo je UNIDU (AZVO, 2012), a posljednje UNIST (AZVO, 2014); u međuvremenu su održana vanjska vrednovanja na UNIZG-u (AZVO, 2013a), UNIOS-u (AZVO, 2013b), UNIRI-u (AZVO, 2013c), UNIPU-u (AZVO, 2013d) i UNIZD-u (AZVO, 2013e). Glavne ocjene prema kriterijima ESG-a ${ }^{5}$

${ }^{5}$ ESG - Standardi i smjernice za osiguravanje kvalitete u Europskom prostoru visokog obrazovanja. ESG 1.1. - Politika kvalitete i postupci za osiguravanje kvalitete; ESG 1.2.1. - Odobrava- 
za pojedino sveučilište navedene su u Tablici 1 . Iz nje je vidljivo da je UNIRI bio najbolje ocijenjen te da je jedini imao jedan kriterij na naprednoj razini, jedan između razvijene i napredne te sve ostale na razvijenoj. S druge strane, UNIST je bio najlošije ocijenjen i jedini je imao dva kriterija između pripremne i početne razine. Pritom treba posebno izdvojiti kriterij ESG 1.1. koji se odnosi na politike kvalitete i procedure sustava $\mathrm{OK}$ jer se $\mathrm{u}$ radu koncentriram upravo na politiku i procedure $u$ OK-u. Prema kriteriju ESG 1.1. vidljivo je da su najlošije ocijenjena tri neintegrirana sveučilišta, a u ukupnoj ocjeni razvijenu fazu ostvaruju samo UNIRI i UNIDU.

Ti nalazi su uglavnom u skladu s onim što je uočeno u analizi zapisnika sjednica senata i ostalih dokumenata javnih sveučilišta koja je predstavljena u idućem dijelu. Veće razlike su vidljive jedino u slučaju UNIDU-a. UNIDU je prvi prolazio proceduru te je u prvotnom izvještaju utvrđeno da su zadaci sustava u početnom stadiju, da je implementacija na pojedinim sastavnicama vrlo različita i da postupak planiranja strateških ciljeva nije jasan. Zaključeno je i da ne postoji jedinstvenost sustava te da smjernice ESG-a nisu dovoljno implementirane, a odgovornosti i ovlasti nejasno su definirane. Nakon dostave Izvješća na UNIDU-u je izraženo neslaganje. Smatrali su da su po određenim kriterijima bili puno uspješniji, a iz konačnog izvješća vidljivo je da su njihovi prigovori prihvaćeni.

Tablica 1. ESG kriteriji na javnim sveučilištima u Hrvatskoj

\begin{tabular}{|l|l|l|l|l|l|l|l|l|l|}
\hline Sveučilište & $\begin{array}{c}\text { ESG } \\
1.1 .\end{array}$ & $\begin{array}{l}\text { ESG } \\
1.2 .1\end{array}$ & $\begin{array}{l}\text { ESG } \\
1.2 .2\end{array}$ & $\begin{array}{c}\text { ESG } \\
1.3 .\end{array}$ & $\begin{array}{c}\text { ESG } \\
1.4 .\end{array}$ & $\begin{array}{c}\text { ESG } \\
1.5\end{array}$ & $\begin{array}{c}\text { ESG } \\
1.6 .\end{array}$ & $\begin{array}{c}\text { ESG } \\
1.7 .\end{array}$ & $\begin{array}{c}\text { Ukupna } \\
\text { ocjena }\end{array}$ \\
\hline UNIDU & $\mathrm{PO} / \mathrm{R}$ & $\mathrm{R}$ & $\mathrm{R}$ & $\mathrm{R}$ & $\mathrm{R}$ & $\mathrm{R}$ & $\mathrm{R}$ & $\mathrm{R}$ & $\mathrm{R}$ \\
\hline UNIOS & $\mathrm{PO}$ & $\mathrm{R}$ & $\mathrm{PO} / \mathrm{R}$ & $\mathrm{R}$ & $\mathrm{R}$ & $\mathrm{R}$ & $\mathrm{PO} / \mathrm{R}$ & $\mathrm{R}$ & $\mathrm{PO} / \mathrm{R}$ \\
\hline UNIPU & $\mathrm{R}$ & $\mathrm{PO}$ & $\mathrm{PO}$ & $\mathrm{R}$ & $\mathrm{PO} / \mathrm{R}$ & $\mathrm{PO} / \mathrm{R}$ & $\mathrm{PO} / \mathrm{R}$ & $\mathrm{R}$ & $\mathrm{PO} / \mathrm{R}$ \\
\hline UNIRI & $\mathrm{R}$ & $\mathrm{R}$ & $\mathrm{R}$ & $\mathrm{R}$ & $\mathrm{R}$ & $\mathrm{R} / \mathrm{N}$ & $\mathrm{R}$ & $\mathrm{N}$ & $\mathrm{R}$ \\
\hline UNIST & $\mathrm{PR} / \mathrm{PO}$ & $\mathrm{PO}$ & $\mathrm{R}$ & $\mathrm{PR} / \mathrm{PO}$ & $\mathrm{PO} / \mathrm{R}$ & $\mathrm{R}$ & $\mathrm{R}$ & $\mathrm{R}$ & $\mathrm{PO} / \mathrm{R}$ \\
\hline UNIZD & $\mathrm{PO} / \mathrm{R}$ & $\mathrm{PO} / \mathrm{R}$ & $\mathrm{PO} / \mathrm{R}$ & $\mathrm{R}$ & $\mathrm{R}$ & $\mathrm{PO} / \mathrm{R}$ & $\mathrm{PO} / \mathrm{R}$ & $\mathrm{R} / \mathrm{N}$ & $\mathrm{PO} / \mathrm{R}$ \\
\hline UNIZG & $\mathrm{PO}$ & $\mathrm{R}$ & $\mathrm{PO} / \mathrm{R}$ & $\mathrm{R}$ & $\mathrm{R}$ & $\mathrm{R}$ & $\mathrm{R}$ & $\mathrm{R}$ & $\mathrm{PO} / \mathrm{R}$ \\
\hline
\end{tabular}

$\mathrm{PR}$ - pripremna faza, $\mathrm{PO}$ - početna faza, $\mathrm{R}$ - razvijena faza, $\mathrm{N}$ - napredna faza Izvor: prilagođeno iz Dodiković-Jurković et al. (2014: 109) i AZVO (2014)

nje, praćenje i periodična vrednovanja programa i kvalifikacija; ESG 1.2.2. - Znanstveno-istraživački rad; ESG 1.3. - Ocjenjivanje studenata; ESG 1.4. - Osiguravanje kvalitete nastavnika; ESG 1.5. - Obrazovni resursi i pomoć studentima; ESG 1.6. - Informacijski sustav; ESG 1.7. - Informiranje javnosti. 


\section{Politika osiguravanja kvalitete na javnim sveučilištima od 2001. do 2013. godine}

Sveučilište u Zagrebu

Pitanje OK se u manjoj mjeri javlja u početnim godinama promatranog perioda i u okviru rasprava o studentskoj anketi. Po pitanju angažmana ističe se sudjelovanje u Tempus projektu Development of Quality Assurance System in Higher Education. U njemu su sudjelovala tadašnja četiri javna sveučilišta UNIZG, UNIST, UNIOS i UNIRI, a UNIZG je bio i nositelj. Tada je na UNIZG-u izrađen Priručnik za uspostavu sustava upravljanja kvalitetom. U pogledu OK bio je značajan i dokument Iskorak 2001 (UNIZG, 2002) kojim su detektirane glavne slabosti institucije te je istaknut nerazvijen sustav OK. Ipak, OK je prepoznat kao važan korak prema integraciji sastavnica u Sveučilište te europski prostor visokog obrazovanja. Tako se navodi nedjelotvornost i nerazvijenost tadašnjeg stanja po pitanju OK, otpor akademske zajednice prema promjeni i dezintegiranost Sveučilišta, ali i izostanak prikupljanja podataka na kojima bi se temeljio OK. Iz toga je očito da postoje pojedine prepreke povezane s institucionalnom organizacijom koje se očituju u neintegriranosti. Nastavno, vidljiv je kružni problem odnosa neintegriranosti i OK. Naime, smatra se da će uspostava sustava OK sama po sebi riješiti pitanje neintegriranosti, a kao prepreka uspostavi sustava OK prepoznaje se neintegriranost. Kao cilj postavljeno je stvaranje kulture i politike kvalitete te razvoj i primjena općeg sustava OK kroz samoanalizu, pokazatelje kvalitete, studentsko vrednovanje nastavnika. Iste godine osnovan je i Odbor za osiguravanje kvalitete koji za cilj ima rad na razvoju mreže za OK i kulturu kvalitete, provedbu unutarsveučilišne evaluacije i usustavljivanje studenske ankete o kvaliteti nastave.

Sveučilištu je 2004. godine dostavljeno Izvješće Salzburg seminara koje se temelji na posjetima inozemnih stručnjaka nizu sveučilišta. Rasprava o dostavljenom izvješću ponovno je otvorila pitanje kvalitete te razmatranje potrebe za razvijanjem unutrašnjih kriterija kvalitete. Prorektorica Vizek-Vidović napomenula je da uspostavu mehanizama OK ne mogu provoditi privremena povjerenstva te da je potrebno profesionalizirati to područje, a da je postizanje kvalitete važno zbog uključivanja u europske integracijske procese sadržane u Bolonjskoj deklaraciji, čime su istaknuti glavni pokretači promjene. Daljnji razvoj je temeljen na tri projekta Nacionalne zaklade za znanost, visoko školstvo i tehnologijski razvoj za potrebe izgradnje institucijskih mehanizama za unapređenje kvalitete.

Tijekom 2006. godine uspostavljen je Ured za upravljanje kvalitetom, Odbor za osiguravanje kvalitete je preimenovan u Ured za upravljanje kvalitetom, a prijelaz prema sustavnijem provođenju OK napravljen je u akademskoj godini 2007./2008. Tada je donesen Plan aktivnosti u području upravljanja čija su glavna područja djelovanja bila unapređenje formalnopravnog i organizacijskog okruženja, razvoj ljud- 
skih potencijala, institucijska (samo)evaluacija $i$ istraživanje, evaluacija nastavnih procesa $\mathrm{i}$ ishoda nastave te mjere za unapređenje kvalitete. Vidljivo je da u tom trenutku ne postoji pravilnik o sustavu upravljanja kvalitetom, da nema povjerenstava za upravljanje kvalitetom na sastavnicama, ne postoji pravilnik o vrednovanju kvalitete nastave ni priručnik za kvalitetu što zrcali nasljeđe započetog puta historijskog razvoja u kojem su sastavnice uglavnom samostalne organizacijske jedinice. Stoga je istaknuto da su to ciljevi koje treba ostvariti te sustavno planirati sredstva za upravljanje kvalitetom na razini Sveučilišta. Motivi za usustavljivanje mogu se prepoznati u izjavama prorektorice Pinter koja ističe da je uspostava sustava OK temeljna pretpostavka za uključivanje $u$ europski prostor visokog obrazovanja.

S obzirom na postavljene ciljeve, 2010. godine pokrenuta je javna rasprava o prijedlogu Pravilnika o sustavu upravljanja kvalitetom obrazovanja Sveučilišta u Zagrebu. Prorektorica Pinter naglasila je da je Zakonom o osiguravanju kvalitete propisano kako se moraju uspostaviti sustavi OK te da se to Pravilnikom želi i postići. Na njegovo prihvaćanje čekalo se sve do siječnja 2011. Odbor za upravljanje kvalitetom radio je na izradi Pravilnika te na Priručniku, a zatim i na Pravilniku o vrednovanju studijskih programa preddiplomskih i diplomskih studija. Također je zaključeno da je UNIZG tek na početku uspostave sveobuhvatnog i učinkovitog sustava OK, a kao zadaća je postavljena uspostava sustava OK u svim područjima djelovanja te razvoj kulture kvalitete. Istaknuto je kako je pokretanje Bolonjskog procesa u prvi plan stavilo potrebu uvođenja i poštivanja kriterija. Upravo u takvoj argumentaciji vodećih ljudi UNIZG-a može se prepoznati da glavni poticaji za uspostavu sustava OK dolaze s europske razine, ali i s nacionalne razine u vidu zakonskih propisa, $\mathrm{tj}$. postoje egzogeni mehanizmi koji pokreću promjenu politike.

Nadalje, primjetno je da je 2011./2012. još uvijek prioritet izrada Priručnika za osiguravanje kvalitete za koji je 2007./2008. istaknuto da je hitno potreban. Priručnik je donesen u lipnju 2012. godine i osnovna zadaća mu je bila povezati dotadašnja iskustva i aktivnosti na UNIZG-u sa Standardom i smjernicama za osiguravanje kvalitete u Europskom prostoru visokog obrazovanja. Od 2010. do 2012. godine izrađivan je i dokument Razvoj i preobrazba Sveučilišta u Zagrebu (UNIZG, 2013). U njemu je prikazano tadašnje trenutno stanje sustava OK. Kao glavni razlog za uspostavu formalno-administrativnog okvira navodi se utjecaj uspostave sustava vanjskih vrednovanja na europskoj i nacionalnoj razini, ali i potreba za jasnijim promišljanjem razvoja. Dan je i osvrt na nepostojanje ujednačenog razvoja na svim sastavnicama, ali i na problem s ingerencijama u pojedinim područjima sustava. U tom pogledu još jednom dolazi do izražaja pitanje neintegriranosti, koje i deset godina nakon dokumenta Iskorak 2001 priječi promjenu politike OK. Utjecaj institucionalnog nasljeđa i uređenja vidljiv je u nemogućnosti ujednačavanja sustava $i$ praksi na razini sustava i sastavnica. 
Povjerenstvo za unutarnju prosudbu sustava kvalitete je 2012. godine izradilo izvješće i plan aktivnosti za naknadno praćenje sustava OK nakon provedene unutarnje prosudbe. U pripremi za vanjsko vrednovanje posebno su se osvrnuli na prvi ESG kriterij koji se odnosi na objavljene dokumente poput politike kvalitete, misije, vizije i strategije. Istaknuto je da su krajem 2010. godine prihvatili dokument Razvoj i preobrazba Sveučilišta u Zagrebu - Polazne pretpostavke, a da postoje i pojedine parcijalne strategije te da je u izradi prijedlog Politike kvalitete. Tako je u listopadu 2012. godine donesen i dokument pod nazivom Politika osiguravanja kvalitete na Sveučilištu u Zagrebu.

Konačno, vanjska procjena o unutarnjem sustavu OK koju je 2013. objavio AZVO ističe upravo institucionalne značajke koje karakteriziraju UNIZG kao primjer nedostataka koje su uočili (AZVO, 2013a). Ti su nedostaci, među ostalim: izostanak jedinstvenog i cjelovitog strateškog dokumenta, veličina sveučilišta i njegovo institucionalno uređenje, zbog čega je i otežan razvoj jedinstvenih postupaka OK, zatim to što je postupak donošenja dokumenata dugotrajan, dokumentacija nekonzistentna, a razvoj među sastavnicama neujednačen. Od prednosti koje su uočili ističu se prepoznavanje kulture kvalitete i formalni ustroj kvalitete.

\section{Sveučilište u Splitu}

Osim samoanalize sastavnica 2002. godine na UNIST-u nije bilo točaka i rasprava na Senatu o pitanju OK sve do akademske godine 2004./2005. kada je imenovan koordinator za promicanje kvalitete u nastavi i znanosti, a osnovano je i Povjerenstvo za praćenje kvalitete nastave i znanosti. Nadalje, akademske godine 2005./2006. izvršena je analiza studiranja prema novim nastavnim programima te je odlučeno da će se ujednačiti metodologija analize rezultata i kontinuirano provoditi mjere za unapređenje kvalitete studija. Vijeća sastavnica su bila dužna razmotriti rezultate i dostaviti zaključke. Međutim, rasprava o zaključcima nije pronađena u zapisnicima. Akademske godine 2006./2007. osnovan je Centar za unaprjeđenje kvalitete te su prema Statutu UNIST-a i sve sastavnice bile dužne osnovati vlastite odbore za unapređenje kvalitete do kraja lipnja 2007. godine. Iako osnivanje nije zabilježeno u zapisnicima sjednica, u Priručniku za osiguravanje kvalitete UNIST-a stoji da su Centar za unaprjeđenje kvalitete na razini Sveučilišta i Odbori za unaprjeđenje kvalitete na razini sastavnica osnovani na sjednici Senata 11. rujna 2008. godine te se to uzima kao polazišna točka za institucionalni razvoj kvalitete. Tada je donesen i Pravilnik o Centru i Odborima za unaprjeđenje kvalitete koji sadržava i misiju, viziju, ciljeve i područje djelovanja Centra i Odbora, pa se to (eventualno) može smatrati činom ustrojavanja. U pogledu UNIST-a primjećuje se prilično malo rasprava u vezi s pitanjima kvalitete, a početak aktivnijeg bavljenja tim pitanjima dolazi kasnije nego kod ostalih sveučilišta. 
Nadalje, analiza uspješnosti studiranja po sastavnicama pokazuje postojanje problema s omjerom studenata i nastavnika, problema adekvatnog prostora te dislociranosti pojedinih sastavnica. To ukazuje na dvostruke prepreke. Jedne proizlaze iz kapaciteta aktera za OK, a druge se temelje na institucionalnoj strukturi čija neintegriranost onemogućuje provedbu pojedinih ciljeva te politike. U tom je pogledu 2010./2011. donesen Akcijski plan s mjerama aktivne kadrovske politike kojima se nastoji optimizirati omjer nastavnika i studenata te provođenje racionalizacije studijskih programa. Tijekom 2011./2012. doneseni su Pravilnik o centru i odborima za unapređenje kvalitete, Pravilnik o ustroju i ulozi sustava upravljanja kvalitetom te Pravilnik o postupku vrednovanja studijskih programa. Osim toga, u listopadu 2012. godine donesen je Priručnik osiguravanja kvalitete, a u siječnju 2013. godine Politika osiguravanja kvalitete u skladu s preporukama Povjerenstva za vanjsku periodičnu prosudbu sustava osiguranja kvalitete. U Priručniku su navedeni postupci koji služe za razvoj kvalitete poput analize uspješnosti studiranja, upisa i motivacije studenata, anketiranja studenata, anketiranja nastavnog osoblja, institucijske provjere kvalitete, analize uspješnosti, diseminacije rezultata i drugo. Iz toga je vidljivo da intenzivniji rad u tom području slijedi nakon donošenja Zakona o osiguravanju kvalitete 2009. godine, što upućuje na izvanjske pokretače promjene politike te $t i$ ming promjena koje dolaze tek nakon tog vanjskog utjecaja.

U travnju 2013. godine objavljeno je Izvješće unutarnje prosudbe sustava za unapređenje kvalitete koje ističe nepostojanje sveobuhvatne strategije, ali da je ista $\mathrm{u}$ izradi te da pojedine sastavnice imaju vlastite strategije razvoja. Nadalje, većina sastavnica nije imala priručnike OK, na pojedinima nije bio donesen Pravilnik o ustroju i ulozi OK, nije postojao definiran postupak provođenja aktivnosti sustava OK i njihovog nadzora, kao ni detaljni postupak unutarnje prosudbe učinkovitosti sustava OK na razini sveučilišta i sastavnica. Osim toga, prepoznata je i potreba za integracijom sustava za praćenje nastave i uspjeha studenata na razini sveučilišta te razvoja sustava za kadrovsko, administrativno i financijsko praćenje. Tako je i unutar UNIST-a prepoznato da postoje problemi povezani s OK-om koji proizlaze iz institucionalnog naslijeđa institucije, ali i nedostaci po pitanju kapaciteta za provedbu politike OK. Slični zaključci proizlaze i iz vanjske procjene AZVO-a (2014) u kojoj se kao nedostaci ističu nepostojanje opće Strategije kao referentne točke, slaba aktivnost sustava OK i funkcionalna neintegriranost, neujednačenost među sastavnicama, nepostojanje pokazatelja o funkcioniranju sustava, nedefiniranost politike kvalitete na svim sastavnicama i financijska ograničenja u vidu stimulacije osoba koje rade u nadležnim tijelima. Među prednostima se ističe da su uspostavljeni formalni mehanizmi te da se u periodu koji je neposredno prethodio vanjskoj procjeni učinilo mnogo. 
Sveučilište Josipa Jurja Strossmayera u Osijeku

U prve dvije godine promatranog razdoblja nema značajnijih rasprava po pitanju politike OK na sjednicama Senata. Na UNIOS-u se tek sporadično dotiču pojedinih tema povezanih s OK-om. Tako je provedena analiza uspješnosti studiranja, a istaknute poteškoće povezane su s nedostatkom prostora te $\mathrm{s}$ lošom opremljenosti. Tako se već na samom početku promatranog razdoblja mogu vidjeti problemi s kapacitetima nužnima za promjenu politike. Ti problemi su vidljivi i iz godišnjih izvješća dekana koji naglašavaju značajan nedostatak prostora te manjak nastavnog kadra, što upućuje na pitanje kapaciteta kao prepreku u promjeni politike. Pitanje kvalitete se ističe kao ključno za 2002. godinu te se napominje da je UNIOS postao članom Europske Sveučilišne Udruge (EUA) potpisivanjem Konvencije iz Salamance i da je kvaliteta postavljena kao temelj europskog visokog obrazovanja. Upravo argumenti uključivanja u europski prostor visokog obrazovanja i Bolonjski proces često se koriste i u daljnjem razvoju te politike i jasno se mogu vidjeti egzogeni pokretači promjene.

Krajem 2002. godine počinje razmatranje pitanja OK te je istaknuta potreba izrade i provedbe studentske ankete. U vezi s prihvaćanjem Bolonjske reforme ističe se da je kvaliteta u obrazovanju primarni zadatak te da je cilj dostići razinu dobrih europskih sveučilišta. Postupna izgradnja sustava je nastavljena 2004./2005. donošenjem odluke o ustroju Odbora za nastavu i kadrovsku politiku koji ima ulogu stručno-savjetodavnog tijela te predlaže mjere za unapređivanje i OK nastave, priprema analize i izvješća za vrednovanje nastavne djelatnosti. Tijekom 2006. godine Nacionalna zaklada za znanost, visoko školstvo i tehnologijski razvoj odobrila je UNIOS-u projekt pod nazivom Uspostavljanje sustava unaprjeđenja kvalitete obrazovanja. Slijedom toga imenovani su Odbor i Služba za unaprjeđenje i osiguranje kvalitete visokog obrazovanja te povjerenstva za praćenje i osiguranje kvalitete visokog obrazovanja na sastavnicama, a planiralo se i ustrojavanje Sveučilišnog centra za unaprjeđenje i osiguranje kvalitete obrazovanja. Izrađen je strateški plan unaprjeđenja kvalitete te je u rujnu 2006. godine usvojen Pravilnik o ustroju i djelovanju sustava za osiguranje kvalitete. Kao glavni cilj Pravilnika istaknuto je poboljšanje kvalitete studiranja.

Nadalje, provedena je i analiza indikatora kvalitete za razdoblje od 2001. do 2005., ali je istaknuto da je dio podataka nepotpun i neprikladan, što pokazuje da u prethodnom periodu nije ostvaren preduvjet za OK, a to je praćenje procesa i osiguravanje relevantnih pokazatelja za unapređivanje kvalitete. Taj problem proizlazi djelomično i iz neintegriranosti Sveučilišta, što rezultira neujednačenim praksama praćenja podataka i konačno nemogućnosti njihove komparacije. Zato je 2006./2007. ponovno naglašeno da je OK među glavnim postavkama Bolonjskog procesa te postoji ideja da se na osnovi autonomije institucije zahtijeva odgovornost 
i da sveučilište bude nositelj odgovornosti u procesu razvoja interne kulture kvalitete. Izrađen je strateški plan kojim je definirana struktura, organizacija i vodstvo sustava $\mathrm{OK}$, a istaknuta je potreba ustrojavanja jedinica za OK na sastavnicama. U tom pogledu kreiran je i plan aktivnosti sustava osiguranja i unapređenja kvalitete za 2007./2008. u kojem je planirana jedinstvena studentska anketa, praćenje indikatora kvalitete, anketiranje studenata o radu, radionice, planiranje i praćenje aktivnosti sustava kvalitete, diseminacija informacija, koordinacija sudionika sustava $i$ dodatna edukacija.

U prosincu 2011. godine donesena je Strategija Sveučilišta za razdoblje 2011.2020. (UNIOS, 2011). U njoj je prepoznato nedostatno praćenje kvalitete nastave i nerazrađen sustav praćenja kvalitete. Kao rješenje za daljnji razvoj ponovno se predviđa osnivanje jedinstvenog sveučilišnog centra za praćenje kvalitete obrazovanja, ali i ustrojavanje jedinica za praćenje OK na sastavnicama. To pokazuje da UNIOS nije bio u mogućnosti provesti promjene na sastavnicama najavljene 2006./2007., ali ni centar na razini Sveučilišta koji bi koordinirao procese, te isti strukturni problemi i dalje ostaju prisutni. Ističe se i da je za iduće razdoblje potrebno osigurati prostorne i financijske uvjete, ali i stručnjake koji će raditi na sustavu OK, što jasno pokazuje da ne postoje potrebni kapaciteti za provedbu promjene politike OK. Provedena je analiza implementacije Bolonjskog procesa koja također ističe probleme s manjkom kadra i prostornim kapacitetima te potrebu daljnje izgradnje sustava $\mathrm{OK}$ i osnivanja jedinstvenog sveučilišnog centra. OK je pritom predstavljen kao podloga za integraciju UNIOS-a u zajednički europski obrazovni sustav. Ideja osnivanja jedinstvenog sveučilišnog centra, koja je najavljivana prethodnih godina, ostvarena je u lipnju 2012. godine, a iste godine je izrađen i Priručnik kvalitete. Osnovani Centar ima cilj unaprijediti i osigurati kvalitetu obrazovanja kako bi UNIOS postao prepoznatljiv i konkurentan u europskom visokoškolskom prostoru.

Konačno, vanjska procjena AZVO-a (2013b) detektirala je nedostatke među kojima se nalaze opterećenost osoblja, česta promjena dokumentacije, neintegriranost sastavnica u sustav OK i nepostojanje pojedinih dokumenata na sastavnicama, neharmoniziranost sustava na razini Sveučilišta, nepovezanost postupaka za OK i nesustavna provedba unutarnje prosudbe kvalitete po sastavnicama. Među prednostima na UNIOS-u ističu se postojanje Strategije na razini Sveučilišta, uspostavljenost dobrog formalnog okvira sustava te prepoznavanje studenata kao ravnopravnih dionika u segmentu OK.

\section{Sveučilište u Rijeci}

Na UNIRI-u su 2001. godine izvršene predradnje za provedbu studentske ankete, osnovano je Povjerenstvo za unapređenje nastave te je raspravljano Izvješće specijalnog tima Salzburg seminara u kojem je istaknuta potreba stalnog praćenja kva- 
litete. Iz tog razloga odlučeno je da se toj temi posveti više pažnje u raspravama Senata. Početkom akademske godine 2002./2003. pripremalo se osnivanje Ureda za promicanje kvalitete na Sveučilištu u Rijeci te je to predstavljeno kao temeljni zahtjev Bolonjske deklaracije. Ured je osnovan početkom 2003. godine, a najavljeno je i formiranje radnih grupa za promicanje kvalitete na sastavnicama. Istaknuto je da se Sveučilište mora brinuti za kvalitetu, prihvatiti kriterije kvalitete, provoditi samoanalize te istraživanja mišljenja studenata uz kontinuirano unapređivanje. Takve prakse pokazuju da se na UNIRI-u već početkom promatranog razdoblja bave pitanjima OK te da postoji svijest o važnosti ravnomjernog razvoja na svim sastavnicama. UNIRI se uključio i u Quality Culture Project koji organizira EUA, a cilj je stvaranje europskog modela sustava za kontrolu kvalitete. UNIRI je bio jedino hrvatsko sveučilište od 50 europskih uključenih u projekt. Iste godine najavljeno je i osnivanje Odbora za promicanje kvalitete u kojem će biti predstavnici svih sastavnica, a u studenom 2003. održan je sastanak s voditeljima timova te su dogovorene prve analize. Takav potez ukazuje na povezivanje razine sveučilišta i pojedinih sastavnica što je važan institucionalni segment kojim se premošćuje pravna osobnost sastavnica i nastoji se osigurati funkcionalno integriranje sustava OK. U skladu s naglašavanjem zahtjeva iz Bolonjske deklaracije i prorektor Lučin je istaknuo da je na sastanku ekspertne europske grupe Bologna Follow-up zaključeno da se do 2005. godine treba uspostaviti mreža za unapređivanje kvalitete.

Pitanje kvalitete je ugrađeno i u Statut donesen u veljači 2004. godine. Tada je naglašeno kako je poticanje integrativnih procesa važan korak prema promišljanju razvoja Sveučilišta, što se može prepoznati, u skladu s teorijskim pretpostavkama ovog rada, kao važna osnova za olakšavanje promjene politike. Nastavno, rektor Rukavina je istaknuo pozitivne pomake i kvalitetu kao temeljni zahtjev Bolonjskog procesa, iz čega se može iščitati i odakle dolaze poticaji promjeni. Tako je naglasio da:

Sveučilište u Rijeci na kvaliteti radi sustavno od 2001. godine. To možemo argumentirati brojnim podacima: jedini smo među hrvatskim sveučilištima organizirali sustav za promicanje kvalitete; u Statutu smo se obvezali izgraditi sustav za osiguranje i upravljanje kvalitetom i na tome radimo najintenzivnije u Hrvatskoj; donijeli smo Etički kodeks, a danas ćemo usvojiti i dodatak Etičkom kodeksu koji regulira postupke i koji je podloga za izgradnju sustava kvalitete; fakulteti su trebali ugradili odredbe o kvaliteti u svoje Statute. (UNIRI, 2004: 2)

U sličnom je duhu bila i izjava rektora u novinama, gdje je naglasio da svaka sastavnica razvija svoju organizacijsku jedinicu za OK, ali da će njihov rad koordinirati središnji Sveučilišni centar za unapređivanje kvalitete (Marinković Škomrlj, 2005). Takvi postupci ukazuju na postojanje koordiniranog pristupa kojim se povezuju sveučilište i sastavnice, što je dodatan korak u institucionalnom razvoju i homogenijem razvoju politike $\mathrm{OK}$. 
U tom stadiju bilo je pojedinih problema, pa se tako na sjednicama ističe postojanje ignorancije, inercije i otpora promjenama, vladanje mehanizma nezamjeranja, a kao ključna točka poboljšanja kvalitete detektirana je sustavna provedba studentske evaluacije nastavnika te korištenje kontrolnih mehanizama u vidu sankcioniranja i nagrađivanja. Unatoč nekim problemima, na UNIRI-u su isticali da su svojim djelovanjem postali primjer dobre prakse, a tome svjedoči i interes UNIOS-a za provedbom njihove studentske ankete. Nastavak rada na uspostavi sustava OK ostvaren je i prijavom projekta Razvoj organizacijskog sustava i postupaka za unapređenje kvalitete na natječaj Nacionalne zaklade za znanost, visoko školstvo i tehnologijski razvoj, gdje je taj projekt bio najbolje ocijenjen.

Akademske godine 2005./2006. predstavljen je razrađeni organizacijski sustav iz kojeg su jasne nadležnosti i odgovornosti, a radilo se i na izradi Pravilnika o sustavu kvalitete i Priručnika za kvalitetu. Plan aktivnosti je predviđao osnivanje Centra za kvalitetu, prihvaćanje Pravilnika o sustavu kvalitete, izradu Priručnika za kvalitetu, formiranje Odbora za kvalitetu te timova za kvalitetu na sastavnicama, izradu instrumentarija za praćenje kvalitete na različitim razinama, provedbu studentske ankete, razvoj institucijskih mehanizama za unapređenje kvalitete te u konačnici provedbu samovrednovanja i definiranje razvojnih planova. Tako su početkom 2006. godine osnovani Centar i Odbor, a prihvaćen je i Pravilnik. Početkom 2006./2007. konstatirano je da je plan razvoja sustava kvalitete na Sveučilištu uspješno realiziran, ali i da je potrebno ustrojiti održiv sustav OK. Takvi ciljevi su postavljeni i u Strategiji Sveučilišta u Rijeci 2007.-2013. (UNIRI, 2007). Pritom je kvaliteta istaknuta kao temeljna strateška vrijednost UNIRI-a te se ističe važnost integriranog funkcioniranja sustava OK. To pokazuje provedbu te politike s razine samog Sveučilišta usprkos formalnopravnoj osobnosti sastavnica te aktivan rad na promjeni politike $\mathrm{OK}$.

Uspješnost OK pokazuju i izvještaji o provedbi strategije. Tako je već u prvoj godini provedbe Strategije na većini sastavnica postignut zacrtani omjer nastavnika i studenata, a sve sastavnice sustavno kontroliraju kvalitetu i surađuju s centralnim Odborom za kvalitetu. Osim toga, istaknuto je i da je Centar za unaprjeđenje kvalitete preuzeo provođenje većine evaluacijskih aktivnosti na sastavnicama. Napredak $\mathrm{u}$ istom smjeru zabilježen je i u izvještajima za naredne godine. Ta dva primjera ponovno potvrđuju postojanje suradnje sastavnica i sveučilišta, ali i centralno upravljanje procesom, što osigurava jednake kriterije i ujednačavanje standarda na sastavnicama te institucionalnu podlogu za promjenu politike.

U narednom periodu intenzivirane su aktivnosti poput izrade Priručnika za kvalitetu u akademskoj godini 2008./2009. te predstavljanja projekata Uspješnost provedbe Bolonjskog procesa i Implementacija Priručnika za kvalitetu studiranja na Sveučilištu u Rijeci koji su završeni u travnju 2011. godine. U Priručniku se ističe 
da su izgradnja sustava OK i razvoj kulture kvalitete preduvjet za uspješno integriranje u Europski prostor visokog obrazovanja. Tada je predstavljen i cjelokupni sustav te su ga na UNIRI-u smatrali najbolje razrađenim u Hrvatskoj, a kao ključnu točku su istaknuli korištenje podataka i povratnih informacija dobivenih istraživanjem za unapređivanje rada sa studentima.

U skladu s tim, i vanjska procjena unutrašnjeg sustava OK (AZVO, 2013c) istaknula je tek nekoliko nedostataka poput čestih promjena formalnih akata, ponekih nejasnoća u obvezama koje sastavnice trebaju preuzeti i različito definiranih kriterija kvalitete u Strategiji i unutarnjoj prosudbi sustava OK. S druge strane, uočene prednosti potvrđuju nalaze do kojih se došlo i ovim istraživanjem, pa su tako istaknuti pozitivno ozračje, kontinuiran razvoj kulture kvalitete, praćenje indikatora Strategije, prepoznavanje važnosti samovrednovanja i unutarnje prosudbe sustava OK te uključenost studenata kao ravnopravnih dionika u OK.

\section{Sveučilište u Dubrovniku}

Početkom djelovanja na UNIDU je prenijet sustav kvalitete s Veleučilišta u Dubrovniku, ali njime nije bilo obuhvaćeno cjelokupno Sveučilište te je prvi od zadataka bio uvesti ga na preostale dijelove. Po pitanju kvalitete nastave na UNIDU-u su se već u prvoj godini djelovanja javili problemi u vezi s nastavnim kadrom. Za predložene nastavne programe po Bolonjskom procesu imali su samo $21 \%$ potrebnog kadra; iz tog razloga su odustali od prijavljenih diplomskih studija, ali su i nakon toga imali tek $34 \%$ kadra, a zakonski minimum je 50\% stalno zaposlenih nastavnika. Uslijedilo je odustajanje i od nekih preddiplomskih studija, dosegnuta je razina od 46,49\% i tada je ispregovarano da se s takvom pokrivenošću kadra dobije dopusnica za te programe. Dakle, već je u početku vidljivo da postoje problemi s kapacitetima aktera, što predstavlja prepreku za dubinsku promjenu politike OK.

Dotadašnje aktivnosti na Veleučilištu su bile: analiziranje strukture studenata upisanih u prvu godinu studija, prolaznosti i trajanja studija, vrednovanje nastavnih aktivnosti od strane studenata, samoocjenjivanje nastavnika te analiza zapošljavanja diplomiranih studenata. Predloženo je da se iste analize provode i na UNIDU-u. Također, tijekom 2005./2006. kvaliteta nastavnih aktivnosti se anketirala u oba semestra, a rektor je istaknuo i da nastavnici koji dvije godine zaredom dobiju loše ocjene ne bi trebali ostati na Sveučilištu. Međutim, nakon ankete 2006./2007. vidljivo je da ne postoji nikakvo sankcioniranje najslabije ocijenjenih, a ni nagrađivanje najbolje ocijenjenih. Tom prilikom istaknuto je da ne treba posebno nagrađivati najbolje, a da s najslabije ocijenjenima treba obaviti razgovore, pa ako ne poprave rezultate tijekom naredne godine, zahvaliti im se na suradnji. Iste godine je provedena samoanaliza nastavnih djelatnosti te su nastavnici dali prigovore $u$ vezi $s$ prostornim kapacitetima. Nakon što je NVVO usvojio dokumente za vrednovanje 
visokih učilišta koji zahtijevaju opsežnu samoanalizu, na UNIDU-u su odlučili da je potrebno prikupljati i sistematizirati podatke prema dostavljenim parametrima. Poticaj za razvoj sustava OK bilo je i donošenje Zakona o osiguravanju kvalitete iz 2009. godine, te se tako uz poticaj s europske razine prepoznaju i izvanjski poticaji s nacionalne razine. Iz tog razloga imenovano je Povjerenstvo za unutarnji sustav osiguravanja i unapređivanja kvalitete. Uspostava unutarnjeg sustava donosi jedinstven set mjera i aktivnosti kako bi se osigurala kvaliteta ishoda rada, a djelokrug Povjerenstva je provođenje postupka vrednovanja i utvrđivanje kvalitete, prikupljanje i obrada podataka, rad na uključivanju i povezivanju u međunarodna udruženja i mreže koje se bave OK. Nadalje, vanjska procjena unutrašnjeg sustava OK (AZVO, 2012) kao nedostatke sustava ističe preopterećenost osoblja, nejasno definirane odgovornosti i ovlasti, nepostojanje jedinstvenog sustava i različitu implementaciju na pojedinim sastavnicama. S druge strane, kao prednosti se ističu integriranost, potpora razvoju sustava $\mathrm{OK}$, donošenje svih važnih dokumenata i postojanje svijesti o promicanju kulture kvalitete.

Sam sustav kvalitete je AZVO ocijenio pozitivnim i u razvijenoj fazi, ali se može primijetiti da u nekim područjima, poput studentske ankete, ta politika zapravo nije na toj razini. Nesustavan pristup pokazali su nastavnici akademske godine 2010./2011. pri ispunjavanju samoanalize nastavnih aktivnosti. Naime, veći broj njih nije dostavio popunjeni obrazac iako je to bila obveza. Time se pokazuje da su uspostava formalnih procedura i neformalni postupci u suprotnosti. To se potvrdilo i u anketi o kvaliteti nastavnih aktivnosti gdje je, kako se navodi u zapisniku Senata, posebno istaknuto nezadovoljstvo zbog izostanka reakcije Uprave na loše rezultate pojedinih nastavnika kroz duže razdoblje te da studenti zbog toga anketu smatraju nepotrebnom. Ipak, napredak je vidljiv u akademskoj godini 2011./2012. pri samoanalizi nastavnih aktivnosti. Tada su prvi put otkad se provodi samoanaliza svi nastavnici ispunili obrazac.

U akademskoj godini 2012./2013. došlo je i do revidiranja i ažuriranja Politike kvalitete koja je donesena na početku rada UNIDU-a. Njome je razrađeno upravljanje kvalitetom, razvoj sustava i kvalitete različitih područja, te je ona temeljni dokument za izradu operativnih planova. Istaknuto je da je održavanje i razvijanje sustava OK vođeno vlastitom inicijativom, utjecajima tržišta i međunarodnim propisima. Konačno, u svibnju 2013. godine donesena je i Strategija osiguravanja kvalitete. Ta Strategija obuhvaća sva relevantna područja povezana s kulturom kvalitete, od sustava OK preko kvalitete nastave pa do ljudskih i prostornih resursa. U pogledu UNIDU-a nisu vidljive značajnije institucionalne prepreke, ali pitanje kapaciteta dolazilo je do izražaja te je njihov manjak, uz nesustavan pristup, onemogućavao dublju promjenu politike OK. 
Sveučilište u Zadru

Na UNIZD-u tijekom 2002./2003. nema rasprava o temama povezanim s OK-om, a iduće se akademske godine otvara pitanje postojanja službi poput Ureda za promicanje kvalitete. Rektor Magaš je istaknuo kako je Ministarstvo donijelo odluku da sva sveučilišta moraju osnovati Ured za promicanje kvalitete. Na UNIZD-u tad nije bilo službe $u$ formi ureda, nego se čekalo odobrenje novih radnih mjesta za njegovu uspostavu. Osim tih kadrovskih nedostataka, napravljena je i analiza koja je pokazala da je omjer nastavnika i studenata takav da nijedan odjel ne bi prošao evaluaciju, a ističe se i problem s prostornim kapacitetima. To se odražava i na kvalitetu nastave, te je istaknuto da ne postoje uvjeti za održavanje nastave prema Bolonjskom procesu, ali da se treba ponašati kao da je to moguće. Tako se već u samom startu može primijetiti ozbiljan problem s nedostatkom kapaciteta aktera, što je jedna od pretpostavki iznesenih u teorijskom dijelu za provedbu promjene politike OK.

Formalna uspostava sustava OK započela je 2004. godine kada je donesena odluka o osnivanju Ureda za promicanje kvalitete, a početkom 2005. uspostavljeno je Povjerenstvo za praćenje kvalitete. Međutim, reakcija rektora Magaša u ožujku 2006. godine, kada je istaknuo da Ured nije napravio mnogo, da nije ostvario konkretne rezultate te da očekuje konkretnije korake po pitanju unutarnje evaluacije upućuje da je u prve dvije godine postojanja uloga Ureda zapravo bila više formalna. Rektor je to potvrdio i izjavom u novinama (Vukosav, 2006: 17), gdje je istaknuo da se primjenjuje samo manji dio mjera samovrednovanja i razloge za takvu situaciju pronašao u nedostatnom broju ureda i logistike. Taj slučaj ponovno pokazuje nedostatak kapaciteta te samo formalnu uspostavu sustava, ali treba istaknuti da je vidljivo da se sustav OK uspostavlja na razini Sveučilišta te nastoji uskladiti među sastavnicama.

Idući koraci su poduzeti 2009./2010. kada je započeta i rasprava o Pravilniku o sustavu osiguranja kvalitete te je on donesen krajem 2009. godine, a donesen je i zaključak o potrebi izrade Priručnika. Prepoznata je raznovrsnost i nesustavnost rješenja po pitanju OK te je 2010./2011. pokrenuta inicijativa za donošenje zajedničkih standarda, mjerila i kriterija kvalitetnog funkcioniranja sastavnica. Naime, zaključeno je da postoje različita shvaćanja i interpretacije kvalitete pa konačno i realizacija iste na pojedinim sastavnicama. Ustanovljen je i različit stupanj razvoja na pojedinim sastavnicama. Tako neke nisu imale akte, a neke nisu ni imenovale svoja povjerenstva. Zajednički standardi su identificirani kao prioritet jer, kako je istaknuto, u kontekstu kvalitete već duže vrijeme ništa nije napravljeno, još uvijek ne postoji priručnik, a on je dio zakonske obveze te ga je potrebno donijeti. Tako je 2011. godine pokrenuta inicijativa za izradu politike kvalitete i (pod)strategije kvalitete, a prihvaćeni su i vremenski okviri za odjele koji nisu izradili akte povezane s kvalitetom. To je istaknuto i u Strategiji Sveučilišta u Zadru 2011.-2017. 
(UNIZD, 2011), ali kvaliteta nije izdvojena kao poseban cilj, nego se ugrađuje u pojedine strateške ciljeve te je najavljena izrada posebne strategije za kvalitetu do kraja 2012. godine. Međutim, ona nije donesena u tom vremenskom periodu, a ni do kraja promatranog razdoblja.

Nakon što je u 2011. godini najavljena vanjska prosudba AZVO-a, donesen je plan aktivnosti za cijelu akademsku godinu s ciljem pripreme za vanjsku prosudbu. Stav je da treba voditi računa o tim dokumentima, da ne smiju postati sami sebi svrha te da se to događa po pitanju kvalitete na UNIZD-u. Da je najava vanjske prosudbe osvijestila važnost potrebe rada na kvaliteti, govori i stav predsjednice Povjerenstva za unapređivanje kvalitete koja je smatrala da je to upozorenje da treba sustavno raditi na pitanju kvalitete. U prilog dotadašnjem nesustavnom pristupu ide i to da je bilo članova Povjerenstva koji rijetko ili uopće ne dolaze na sjednice te nisu motivirani ili kompetentni za rad.

Daljnji rad obilježen je donošenjem Politike kvalitete i prihvaćanjem Priručnika kvalitete početkom 2012. godine. Osim toga, ustanovljeno je da povjerenstvo za unutarnju prosudbu kvalitete nemaju svi odjeli, a razlog je što ne postoji kadar za njegovo formiranje. Također je istaknuto da se na Odjelu za ekonomiju povjerenstvo imenuje po potrebi, tj. kad sveučilišno povjerenstvo to zatraži. Problem je i opterećenost članova Povjerenstva koji onda zapostavljaju znanstveni i istraživački rad. Time se potvrđuje uvid da prepreke i neharmoniziranost OK na UNIZD-u ne proizlaze iz institucionalne strukture, nego iz manjka kapaciteta na pojedinim sastavnicama. Izdano je i izvješće koje pruža dodatne informacije o politici OK na UNIZD-u, a izneseni su i problemi. Ističe se da nije uvijek moguće odgovoriti na prigovore studenata $u$ anketama jer ne postoje financijski, prostorni i kadrovski uvjeti, da ne postoje strateški dokumenti i da neke sastavnice nemaju povjerenstva za unutarnju prosudbu ili zbog malog broja djelatnika ili jer to prepuštaju stručnim vijećima. Vanjska procjena unutrašnjeg sustava OK (AZVO, 2013e) ukazuje na nedostatke po pitanju nesustavnosti prikupljanja i korištenja informacija u sustavu OK, neusklađenost i preklapanje strateških dokumenata te neusklađenost dvaju središnjih tijela sustava. Kao prednosti su istaknuti prepoznata potreba za sustavnim razvojem kulture kvalitete i doprinos integraciji, ali uočeno je i nedovoljno korištenje sustava OK za integraciju Sveučilišta.

\section{Sveučilište Jurja Dobrile u Puli}

Na UNIPU-u je akademske godine 2007./2008. nakon rasprave po odjelima na Senat dostavljen Pravilnik o sustavu upravljanja kvalitetom. Stav je da upravljanje nije prikladan termin, ali postoji mišljenje da je takav naziv došao iz MZOS-a te da se treba poslušati. Iz izvješća o radu Glavnog odbora za kvalitetu i Središnjeg ureda za kvalitetu primjećuje se postojanje problema s kapacitetima. Posebno se ističe nedostatak opreme; zanimljivo je izdvojiti da je računalo nabavljeno tek 2011. godine, a 
do kraja akademske godine 2011./2012. nisu bili osigurani printer, skener i softver za obradu podataka. To je presudno u pogledu promjene politike OK jer ne postoje osnovni tehnički kapaciteti kojima bi se omogućila implementacija svih značajki koje su predviđene. Krajem 2010. godine donesen je Priručnik kvalitete, a tijekom 2011. godine provedena je unutarnja prosudba sustava OK te je izdana analiza učinkovitosti sustava za kvalitetu i njegov utjecaj na kvalitetu obrazovanja. U analizi se ističe postojanje znatne razlike $u$ opsegu aktivnosti odbora za kvalitetu sastavnica i neujednačenost praksi, a pojedini postupci kvalitete koji su propisani Priručnikom se ne provode. Izvješće je iznjedrilo prijedlog za usvajanjem Strategije sustava za kvalitetu koji bi povezao sva područja i kojim bi se definirale aktivnosti. Međutim, tijekom promatranog razdoblja taj dokument nije donesen. Pitanju sustava OK posvećena je pozornost i u Razvojnoj strategiji Sveučilišta za razdoblje 2010.-2015. (UNIPU, 2011). U njoj se kao jedna od najvažnijih promjena u sustavu visokog obrazovanja ističe upravo uspostava unutarnjeg sustava OK, i to pod utjecajem Europskog prostora visokog obrazovanja u prethodnih deset godina, što se može prepoznati kao vanjski pokretač promjene.

Akademske godine 2012./2013. donesen je novi Pravilnik o sustavu osiguranja i unaprjeđivanja kvalitete. Ističe se da je ovaj kvalitetnije i konciznije složen te usklađen sa zakonom. Konačno, vanjska procjena unutrašnjeg sustava OK (AZVO, 2013d) kao nedostatke ističe preopterećenost osoblja, nedostatnu internu komunikaciju, slabu upoznatost djelatnika sa sustavom OK, problem kapaciteta u vidu omjera stalno zaposlenih i vanjskih suradnika, manjak sredstava za planirane aktivnosti, nedovoljno korištenje sustava za jačanje integracije i neusklađenost dokumenata. S druge strane, kao prednosti se ističu kontinuirano preispitivanje i poboljšanje kvalitete, praćenje učinkovitosti i poticanje kulture kvalitete.

\section{Rasprava i zaključak}

Iz predstavljenog razvoja politike OK vidljivo je da su glavni pokretači promjena bili egzogeni. Naime, na većini sveučilišta jasno se ističe kako su poticaji na promjenu dolazili s europske razine $u$ vidu priključivanja Bolonjskom procesu, potrebi za približavanjem europskim sveučilištima, uključivanjem u europski prostor visokog obrazovanja, prepoznavanja i konkurentnosti u europskom prostoru visokog obrazovanja, pristupanja u EUA i slično. Takvo viđenje potvrđuje i odgovor stručnjaka iz intervjua na pitanje odakle dolaze poticaji za promjene:

Izvana, iz europskih politika. Dakle, kod nas većina stvari koje se događaju u visokom obrazovanju, zapravo se događaju s poticajem iz europskih politika. Zapravo, to Europa radi vrlo smišljeno. (Stručnjak 1)

Kako pričamo o sustavima osiguravanja kvalitete, oni nisu postajali ni izrijekom u propisima ni kao koncept prisutan na sveučilištima do Bolonjskog procesa. Bo- 
lonjski proces, jedna od glavnih dimenzija je upravo razvoj europskog, europske politike osiguravanja kvalitete, koja je na neki način svoj boom doživila 2005. na Bergenskoj ministarskoj konferenciji kada je donesena odluka da se osnuje EQAR i kada su doneseni prvi ESG, odnosno europske smjernice i standardi za osiguravanje kvalitete u europskom prostoru visokog obrazovanja. (Stručnjak 2)

Osim vanjskog utjecaja s europske razine mogu se detektirati i izvanjski pokretači promjene politike koji su dolazili s nacionalne razine, a koji su djelomično povezani s europskim pokretačima koji se kanaliziraju kroz nacionalne propise $\mathrm{i}$ djelovanje AZVO-a. Naime, ponajviše se ističe da utjecaji dolaze zbog zahtjeva nadležnog ministarstva i AZVO-a. Osim eksplicitnog isticanja samih aktera kako takvi zahtjevi dolaze s europske i nacionalne instance, moguće je primijetiti i implicitne tragove koji upućuju u tom smjeru. To je vidljivo kod većine sveučilišta u vidu timinga u kojem se intenzivnije aktivnosti u vezi s politikom kvalitete poduzimaju nakon najavljenih vanjskih evaluacija unutarnjih sustava OK te formalnim donošenjem dokumentacije u periodu nakon vanjskih evaluacija i zakonskih promjena. Iznimka je svakako UNIRI gdje je postojao konstantan rad i razvoj politike OK, a da nije bio uvjetovan zahtjevima s nacionalne razine, nego internim nastojanjima da se unaprijedi kvaliteta.

Osim pokretača promjene moguće je detektirati i određene prepreke povezane s mogućnostima promjene politike (Tablica 2 na sljedećoj stranici). Kod neintegriranih sveučilišta se kao glavna prepreka pokazuje institucionalna struktura. Kod UNIZG-a, UNIOS-a i UNIST-a ističu se njihova veličina i nepovezanost, iz čega proistječu problemi neharmoniziranosti politike OK, izostanka cjelovite politike koja polazi sa sveučilišta i primjenjuje se na sastavnicama, jednosmjerna komunikacija ili izostanak komunikacije između središnjice i sastavnica, nepovezanost i nestrukturiranost postupaka za OK. U tom smjeru idu i odgovori stručnjaka iz intervjua koji prepoznaju razinu integriranosti kao važnu stavku, a i razlike unutar sveučilišta te tvrde:

činjenica je da su velika sveučilišta dezintegrirana, definitivno je [to] nedostatak u upravljanju i bilo kakvim institucionalnim politikama, to je vrlo jasno. (Stručnjak 2)

kada biste vi išli sada secirati nekakvu ocjenu kvalitete Sveučilišta u Zagrebu, imali biste od iznimno visokih ocjena do iznimno niskih. I onda ovisi gdje se nađe prosjek. Naime, postoji iznimno velika razlika u razini kvalitete između samih sastavnica. (Stručnjak 2)

S druge strane, na integriranim sveučilištima i jednom poluintegriranom (UNIZD, UNIDU i UNIPU) prepreka ne proizlazi iz institucionalne strukture; ona se ističe kao podloga koja osigurava mogućnost promjene, ali zbog nedostatka kapaciteta organizacijskih aktera promjena je otežana. Tako je vidljiva nemogućnost 
provedbe politike OK zbog nedostatka kadra, prostornih kapaciteta, financijskih resursa na tim sveučilištima.

Kao poseban slučaj ovdje se ističe UNIRI. Naime, to Sveučilište je tijekom promatranog perioda imalo kontinuiranu provedbu i promjenu politike OK. Podloga za takav razvoj na UNIRI-u može se detektirati u dostignutom balansu po pitanju institucionalne strukture i postojećih kapaciteta aktera. Naime, unatoč tome što je UNIRI formalnopravno neintegrirano sveučilište, na neformalnoj razini ostvarena je funkcionalna integriranost na temelju koje je, uz odgovarajuće mogućnosti djelovanja aktera, ostvarena promjena politike. Upravo na slučaju UNIRI-a moguće je identificirati u uvodnom dijelu spomenutu kombinaciju uvjeta i specifikaciju konteksta koji prema Raginu (2006) omogućuju odgovor na pitanje kako se promjena dogodila. Za UNIRI se i u intervjuima sa stručnjacima dobila potvrda koja ide u tom smjeru:

Rijetka su visoka učilišta koja su imala kvalitetan strateški dokument. Recimo Sveučilište u Rijeci ima sad već drugi i ono je pratilo, znači na temelju donešenih pokazatelja, stvarno je pratilo realizaciju tih strateških planova i koristilo onda za kreiranje tih razvojnih politika. Dakle, rekla bih da je to donekle bila usamljena praksa do unazad par godina, jer ono što smo mi primijetili [...], čak i ako su bili doneseni strateški dokumenti [...] nedostajala je ta kultura praćenja, znači stvarno onaj feedback i onda kreiranje politika na temelju povratnih informacija i analiza. (Stručnjak 3)

Imali smo tu, kažem, ekipu s riječkog sveučilišta koja je bila aktivna i koja je onda to mogla lakše primijeniti na Riječko sveučilište nego Zagreb, s obzirom na veličinu i uvijek nekako, u Zagrebu, pa, tromost sustava. Znate, tromost sustava gdje vi puno teže aktivirate ljude sa sastavnica na samom sveučilištu. (Stručnjak 1)

Tablica 2. Uvjeti i prepreke

\begin{tabular}{|l|l|l|l|}
\hline & $\begin{array}{l}\text { Uvjeti koji } \\
\text { omogućavaju } \\
\text { promjenu }\end{array}$ & $\begin{array}{l}\text { Prepreke } \\
\text { promjeni }\end{array}$ & Očitovanje u politici OK \\
\hline UNIZG & $\begin{array}{l}\text { Kapaciteti } \\
\text { aktera }\end{array}$ & $\begin{array}{l}\text { Neintegrirana } \\
\text { institucionalna } \\
\text { struktura }\end{array}$ & $\begin{array}{l}\text { - Izostanak jedinstvenog i cjelovitog strateškog } \\
\text { dokumenta } \\
\text { - Dugotrajan postupak donošenja dokumenata } \\
\text { - Nekonzistentna dokumentacija } \\
\text { - Neujednačen razvoj među sastavnicama } \\
\text { - Izostanak obveze implementacije priručnika za } \\
\text { kvalitetu } \\
\text { - Prepoznavanje kulture kvalitete kao važnog } \\
\text { elementa }\end{array}$ \\
& & $\begin{array}{l}\text { Viđenje sustava OK kao integrativnog elementa } \\
\text { - Formalno ustrojen sustav OK }\end{array}$ \\
\hline
\end{tabular}




\begin{tabular}{|c|c|c|c|}
\hline UNIST & - & $\begin{array}{l}\text { Neintegrirana } \\
\text { institucionalna } \\
\text { struktura } \\
\text { Kapaciteti } \\
\text { aktera }\end{array}$ & $\begin{array}{l}\text { - Izostanak jedinstvenog i cjelovitog strateškog } \\
\text { dokumenta } \\
\text { - Funkcionalna neintegriranost sustava OK } \\
\text { - Neujednačenost na sastavnicama } \\
\text { - Nepostojanje pokazatelja o funkcioniranju } \\
\text { sustava OK } \\
\text { - Nepostojanje definiranih postupaka za OK } \\
\text { - Politika kvalitete nije definirana na svim } \\
\text { sastavnicama } \\
\text { - Financijska ograničenja za davanje stimulacije } \\
\text { osobama koje rade u tijelima za OK }\end{array}$ \\
\hline UNIOS & $\begin{array}{l}\text { Djelomično } \\
\text { dovoljni } \\
\text { kapaciteti } \\
\text { aktera }\end{array}$ & $\begin{array}{l}\text { Neintegrirana } \\
\text { institucionalna } \\
\text { struktura } \\
\text { Djelomično } \\
\text { nepovoljni } \\
\text { kapaciteti } \\
\text { aktera }\end{array}$ & $\begin{array}{l}\text { - Opterećenost osoblja } \\
\text { - Neintegriranost svih sastavnica u sustav OK } \\
\text { - Neharmoniziranost sustava na razini sveučilišta, } \\
\text { ali i djelomično nastojanje uspostave upravljanja } \\
\text { OK na razini sveučilišta } \\
\text { - Jednosmjernost komunikacije između centralne } \\
\text { razine i sastavnica } \\
\text { - Nesustavna provedba unutarnje prosudbe po } \\
\text { sastavnicama } \\
\text { - Manjak kadra i prostornih kapaciteta } \\
\text { - Postojanje jedinstvene Strategije } \\
\text { - Uspostavljen okvir sustava kvalitete }\end{array}$ \\
\hline UNIRI & 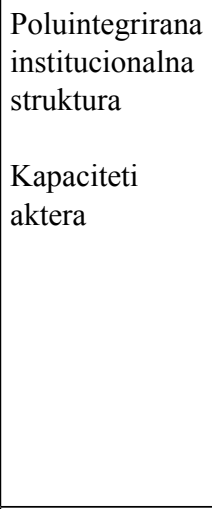 & $\begin{array}{l}\text { Djelomični } \\
\text { individualni } \\
\text { otpori }\end{array}$ & $\begin{array}{l}\text { - Kontinuirani razvoj kulture kvalitete i sustava } \\
\text { OK } \\
\text { - Postojanje jedinstvene strategije razvoja i } \\
\text { praćenje indikatora strategije } \\
\text { - Upravljanje sustavom OK s razine sveučilišta } \\
\text { - Prepoznavanje važnosti samovrednovanja i } \\
\text { unutarnje prosudbe sustava OK } \\
\text { - Obveza za sastavnice o uvrštavanju odredbe o } \\
\text { kvaliteti u statute } \\
\text { - Ostvareni zacrtani omjer nastavnika i studenata } \\
\text { - Česte promjene normativnih akata } \\
\text { - Nejasnoća u obvezama koje sastavnice trebaju } \\
\text { preuzeti }\end{array}$ \\
\hline UNIDU & $\begin{array}{l}\text { Integrirana } \\
\text { institucionalna } \\
\text { struktura }\end{array}$ & $\begin{array}{l}\text { Kapaciteti } \\
\text { aktera }\end{array}$ & $\begin{array}{l}\text { - Manjak kadra } \\
\text { - Nemogućnost sustavne provedbe pojedinih } \\
\text { mjera } \\
\text { - Potpora uprave razvoju sustava OK } \\
\text { - Doneseni svi bitni dokumenti }\end{array}$ \\
\hline UNIZD & $\begin{array}{l}\text { Integrirana } \\
\text { institucionalna } \\
\text { struktura }\end{array}$ & $\begin{array}{l}\text { Kapaciteti } \\
\text { aktera }\end{array}$ & $\begin{array}{l}\text { - Manjak kadra } \\
\text { - Nedostatan omjer nastavnika i studenata } \\
\text { - Nemogućnost formiranja povjerenstava za OK } \\
\text { - Opterećenost članova povjerenstava }\end{array}$ \\
\hline
\end{tabular}




\begin{tabular}{|l|l|l|l|}
\hline UNIZD & $\begin{array}{l}\text { Integrirana } \\
\text { institucionalna } \\
\text { struktura }\end{array}$ & $\begin{array}{l}\text { Kapaciteti } \\
\text { aktera }\end{array}$ & $\begin{array}{l}\text { - Financijski i prostorni nedostaci } \\
\text { - Prepoznata potreba za sustavnim razvojem } \\
\text { kvalitete }\end{array}$ \\
\hline $\begin{array}{l}\text { UNIPU } \\
\text { institucionalna } \\
\text { struktura }\end{array}$ & $\begin{array}{l}\text { Kapaciteti } \\
\text { aktera }\end{array}$ & $\begin{array}{l}\text { - Preopterećenost osoblja } \\
\text { - Nedostatni tehnološki kapaciteti } \\
\text { - Problem kapaciteta u odnosu stalno zaposlenih } \\
\text { i vanjskih suradnika } \\
\text { - Manjak sredstava za planirane aktivnosti } \\
\text { - Praćenje učinkovitosti } \\
\text { - Poticanje kulture kvalitete }\end{array}$ \\
\hline
\end{tabular}

U radu je analizom razvoja politike OK na javnim sveučilištima u Hrvatskoj odgovoreno na pitanje koji su i kakvi su bili pokretači promjene te koji su uvjeti trebali biti zadovoljeni kako bi se promjena ostvarila, a što je glavna postavka u analizi promjene politika. Također, daje se doprinos razmatranju dinamičnog pogleda na promjenu politike što je jedno od ključnih pitanja u historijskom institucionalizmu koje upućuje na nastojanje da se uvaži i institucionalna struktura i uloga aktera. Tako se pokazuje da struktura može biti preduvjet koji akterima omogućuje provedbu promjene, ali da su pojedine karakteristike aktera, poput njihovih kapaciteta, nužne da bi se promjena i dogodila.

\section{LITERATURA}

AZVO (Agencija za znanost i visoko obrazovanje). 2012. Završno izvješće o rezultatima vanjske neovisne periodične prosudbe sustava osiguravanja kvalitete Sveučilišta u Dubrovniku. https://www.azvo.hr/images/stories/vanjska_prosudba/Zavrsno_izvjesce_vanjske_prosudbe_-_UNIDU.pdf (datum pristupa 28. lipnja 2015).

AZVO. 2013a. Završno izvješće o rezultatima vanjske neovisne periodične prosudbe sustava osiguravanja kvalitete Sveučilišta u Zagrebu. https://www.azvo.hr/images/ stories/vanjska_prosudba/Zavrsno_izvjesce_vanjske_prosudbe_-_UNIZG.pdf (datum pristupa 28. lipnja 2015).

AZVO. 2013b. Završno izvješće o rezultatima vanjske neovisne periodične prosudbe sustava osiguravanja kvalitete Sveučilišta Josipa Jurja Strossmayera u Osijeku. https://www.azvo.hr/images/stories/vanjska_prosudba/Zavrsno_izvje\% C5\%A1\%C4\%87e_Sveu\%C4\%8Dili\%C5\%A1ta_Josipa_Jurja_Strossmayera_u_ Osijeku.pdf (datum pristupa 28. lipnja 2015).

AZVO. 2013c. Završno izvješće o rezultatima vanjske neovisne periodične prosudbe sustava osiguravanja kvalitete Sveučilišta u Rijeci. https://www.azvo.hr/images/stori- 
es/vrednovanja/Zavrsno_izvjesce_vanjske_prosudbe_-_UNIRI.pdf (datum pristupa 28. lipnja 2015).

AZVO. 2013d. Završno izvješće o rezultatima vanjske neovisne periodične prosudbe sustava osiguravanja kvalitete Sveučilišta Jurja Dobrile u Puli. https://www.azvo. $\mathrm{hr} /$ images/stories/vrednovanja/Zavrsno_izvjesce_vanjske_prosudbe_-_UNIPU.pdf (datum pristupa 28. lipnja 2015).

AZVO. 2013e. Završno izvješće o rezultatima vanjske neovisne periodične prosudbe sustava osiguravanja kvalitete Sveučilišta u Zadru. https://www.azvo.hr/images/stories/vanjska_prosudba/Zavrsno_izvjesce_vanjske_prosudbe_-_UNIZD.pdf (datum pristupa 28. lipnja 2015).

AZVO. 2014. Završno izvješće o rezultatima vanjske neovisne periodične prosudbe sustava osiguravanja kvalitete Sveučilišta u Splitu. https://www.azvo.hr/images/stories/vanjska_prosudba/Zavrsno_izvjesce_vanjske_prosudbe.pdf (datum pristupa 28. lipnja 2015).

Berg, Bruce. 2001. Qualitative Research Methods for The Social Sciences. Allyn and Bacon. Boston.

Birkland, A. Thomas. 2006. Lessons of disaster: Policy change after catastrophic events. Georgetown University Press. Washington.

Börzel, Tanja i Thomas Risse. 2000. When Europe Hits Home: Europeanization and Domestic Change. European integration online papers, (4), 15 (November 29). http://papers.ssrn.com/sol3/papers.cfm?abstract_id=302768 (datum pristupa 13. rujna 2015).

Buljan Barbača, Domagoj i Miranda Gojak. 2011. Implementacija sustava upravljanja kvalitetom u visokoškolskoj instituciji. Predstavljeno na 11. hrvatskoj konferenciji o kvaliteti, Hrvatsko društvo za kvalitetu. https:/issuu.com/kvaliteta.net/docs/buljanbarbaca (datum pristupa 2. veljače 2016).

Bulmer, Simon. 2009. Politics in Time Meets the Politics of Time: Historical Institutionalism and the EU Timescape. Journal of European Public Policy, (16), 2: 307-324.

Capano, Giliberto. 2009. Understanding Policy Change as an Epistemological and Theoretical Problem. Journal of Comparative Policy Analysis, (11), 1: 7-31.

Capano, Giliberto i Simona Piattoni. 2011. From Bologna to Lisbon: The Political Uses of the Lisbon 'Script' in European Higher Education Policy. Journal of European Public Policy, (18), 4: 584-606.

Ćubela Adorić, Vera i Goran Đurđević. 2012. Priručnik za kvalitetu kao katalizator razvoja visokog učilišta: Primjer Sveučilišta u Zadru, u: Zbornik radova 12. hrvatske konferencije o kvaliteti, Hrvatsko društvo za kvalitetu: 80-86. https://issuu.com/svijet-kvalitete.com/docs/priru_nik_za_kvalitetu_kao_katalizator_razvoja (datum pristupa 2. veljače 2016).

Dobbins, Michael i Cristoph Knill. 2014. Higher Education Governance and Policy Change in Western Europe: International Challenges to Historical Institutions. Palgrave Macmillan. New York. 
Dodiković-Jurković, Vesna, Jasmina Havranek, Davorka Andorić, Goran Briški i Ivanka Arlović. 2014. Sustavi osiguravanja kvalitete na javnim sveučilištima u Hrvatskoj, u: Zbornik radova 14. hrvatske konferencije o kvaliteti, Hrvatsko društvo za kvalitetu: 104-110. https://issuu.com/kvaliteta.net/docs/hdk_14_konferencija_2014.104-110 (datum pristupa 2. veljače 2016).

Gottschalk, Marie. 2000. The Shadow Welfare State: Labor, Business, and the Politics of Health-Care in The United States. Cornell University Press. New York.

Hall, A. Peter i Rosemary C. Taylor. 1996. Political Science and the Three New Institutionalisms. Political Studies, (44), 5: 936-957.

Havranek, Jasmina, Vesna Dodiković-Jurković i Vesna Petrović. 2013. Implementation of Quality - Management Systems at Higher Education Institutions in Croatia, u: Zbornik radova 13. hrvatske konferencije o kvaliteti, Hrvatsko društvo za kvalitetu: 246-255. https://issuu.com/kvaliteta.net/docs/hdk_cd_11_(datum pristupa 2. veljače 2016).

Hay, Colin. 2006. Constructivist Institutionalism, u: Rhodes, R. A., Binder, S. A. i Rockman, B. A. (ur.): The Oxford Handbook of Political Institutions. Oxford University Press. Oxford, NY: 56-74.

Hill, Michael. 2005. The Public Policy Process. Pearson Longman. Essex.

Howard, Christopher. 1997. The Hidden Welfare State. Tax Expenditures and Social Policy in the United States. Princeton University Press. Princeton, NJ.

Howlett, Michael i Benjamin Cashore. 2009. The Dependent Variable Problem in the Study of Policy Change: Understanding Policy Change as a Methodological Problem. Journal of Comparative Policy Analysis, (11), 1: 33-46.

Hsieh, Hsiu-Fang i Sarah E. Shannon. 2005. Three Approaches to Qualitative Content Analysis. Qualitative Health Research, (15), 9: 1277-1288.

Immergut, M. Ellen. 1998. The Theoretical Core of the New Institutionalism. Politics and Society, (26), 1: 5-34.

Juroš, Luka. 2006. Change, but how quickly? An Institutionalist Analysis of Higher Education Reforms in Slovenia and Croatia after 1990. MSc diss., London School of Economics (ustupljeno od strane autora).

Lončar-Vicković, Sanja, Marina Holjenko, Dubravka Trampus i Zlata Dolaček-Alduk. 2011. Indikatori kvalitete Sveučilišta Josipa Jurja Strossmayera u Osijeku prednosti, nedostaci i razvojne mogućnosti. Predstavljeno na 12. hrvatskoj konferenciji o kvaliteti, Hrvatsko društvo za kvalitetu. https:/issuu.com/kvaliteta.net/ docs/12shdmk_loncarholjenkotrampusdolacek (datum pristupa 2. veljače 2016).

Mahoney, James i Kathleen Thelen. 2010. A Theory of Gradual Institutional Change, u: Mahoney, J. i Thelen, K. (ur.): Explaining Institutional Change. Cambridge University Press. Cambridge, NY: 1-37. 
Mandić, P. D. 1992. Yugoslavia, u: Burton, C. R. i Neave, G. R. (ur.): The Encyclopedia of Higher Education. Vol. 1: National Systems of Higher Education. Pergamon Press. Oxford: 811-820.

Marentič-Požarnik, Barica, Zdenko Lapajne i Bogomir Mihevc. 1989. Higher Education in Yugoslavia: Present Situation, Policy and New Tendencies, u: Šoljan, N. (ur.): Higher Education in Yugoslavia. Andragogical Centre. Zagreb: 57-69.

Marinković Škomrlj, Elvira. 2005. Studentima stvaramo europski standard u kampusu na Trsatu. Novi list, 17. ožujka, str. 9.

Miller, C. Mark. 2010. Neoinstitutionalism, u: Ishiyama, J. T. i Breuning, M. (ur.): $21^{s t}$ Century Political Science: A Reference Handbook. Sage. Thousand Oaks, CA: 2229.

Myers, D. Michael i Michael Newman. 2007. The Qualitative Interview in IS research: Examining the Craft. Information and Organization, (17), 1: 2-26.

North, C. Douglass. 1990. Institutions, Institutional Change and Economic Performance. Cambridge University Press. New York.

Petek, Ana. 2014. Promjena javnih politika, u: Petek, A. i Petković, K. (ur.): Pojmovnik javnih politika. Politička misao. Zagreb: 137-138.

Peters, B. Guy. 1999. Institutional Theory in Political Science: The 'New Institutionalism'. Pinter. London.

Peters, B. Guy, Jon Pierre i Desmond S. King. 2005. The Politics of Path Dependency: Political Conflict in Historical Institutionalism. Journal of Politics, (67), 4: 12751300.

Pierson, Paul. 1996. The Path to European Integration: A Historical Institutionalist Analysis. Comparative Political Studies, (29), 2: 123-163.

Pierson, Paul. 2004. Politics in Time: History, Institutions, and Social Analysis. Princeton University Press. Princeton, NJ.

Pierson, Paul i Theda Skocpol. 2002. Historical Institutionalism in Contemporary Political Science. Political Science: The State of the Discipline, 3: 693-721.

Potkonjak, M. Nikola. 1989. Educational Reforms in Yugoslavia and Changes in Higher Education, u: Šoljan, N. (ur.): Higher Education in Yugoslavia. Andragogical Centre. Zagreb: 45-57.

Proroković, Ana i Inga Tomić-Koludrović. 2011. Bologna in Practice: A Contribution to the Development of Quality Assurance System at the University of Zadar. UNIZD. Zadar.

Ragin, C. Charles. 2006. How to Lure Analytic Social Science Out of the Doldrums. Some Lessons from Comparative Research. International Sociology, (21), 5: 633-646.

Rayner, Jeremy. 2009. Understanding Policy Change as a Historical Problem. Journal of Comparative Policy Analysis, (11), 1: 83-96. 
Real-Dato, Jose. 2009. Mechanisms of policy change: a proposal for a synthetic explanatory framework. Journal of Comparative Policy Analysis, (11), 1: 117-143.

Reich, Simon. 2000. The Four Faces of Institutionalism: Public Policy and a Pluralistic Perspective. Governance, (13), 4: 501-522.

Rhodes, Rod A., Sarah A. Binder i Bert A. Rockman. 2006. Preface, u: Rhodes, R. A., Binder, S. A. i Rockman, B. A. (ur.): The Oxford Handbook of Political Institutions. Oxford University Press. Oxford, NY: xii-xvii.

Richards, David. 1996. Elite Interviewing: Approaches and Pitfalls. Politics, (16), 3: 199-204.

Sabatier, A. Paul. 1999. The Need for Better Theories, u: Sabatier, P. A. (ur.): Theories of the Policy Process. Westview Press. Boulder, CO: 3-17.

Samolovčev, Borivoj. 1989. Higher Education in Yugoslavia: A Historical Overview, u: Šoljan, N. (ur.): Higher Education in Yugoslavia. Andragogical Centre. Zagreb: 13-34.

Sanders, Elizabeth. 2006. Historical Institutionalism, u: Rhodes, R. A., Binder, S. A. i Rockman, B. A. (ur.): The Oxford Handbook of Political Institutions. Oxford University Press. Oxford, NY: 39-55.

Scharpf, W. Fritz. 1997. Games Real Actors Play: Actor-Centered Institutionalism in Policy Research. Westview Press. Boulder, CO.

Scharpf, W. Fritz. 2000. Institutions in Comparative Policy Research. Comparative Political Studies, (33), 6-7: 762-790.

Shepsle, A. Kenneth. 2006. Rational Choice Institutionalism, u: Rhodes, R. A., Binder, S. A. i Rockman, B. A. (ur.): The Oxford Handbook of Political Institutions. Oxford University Press. Oxford, NY: 23-38.

Steinmo, Sven. 2008. Historical Institutionalism, u: Della Porta, D. i Keating, M. (ur.): Approaches and Methodologies in the Social Science: A Pluralist Perspective. Cambridge University Press. Cambridge, NY: 118-138.

Stinchcombe, L. Arthur. 1968. Constructing Social Theories. University of Chicago Press. Chicago.

Šoljan, N. Nikola. 1991. The Saga of Higher Education in Yugoslavia: Beyond the Myths of a Self-Management Socialist Society. Comparative and International Education Society, (35), 1: 131-153.

UNIDU (Sveučilište u Dubrovniku). 2018. Povijest i razvoj. http://www.unidu.hr/obavijest.php?idizbornik=15 (datum pristupa: 12. travnja 2018).

UNIOS (Sveučilište Josipa Jurja Strossmayera u Osijeku). 2011. Strategija Sveučilišta Josipa Jurja Strossmayera u Osijeku 2011-2020. http://www.unios.hr/wp-content/ uploads/2015/07/SJJS_Strategija_Sveucilista_HR.pdf (datum pristupa 15. siječnja 2015). 
UNIPU (Sveučilište Jurja Dobrile u Puli). 2011. Razvojna strategija Sveučilišta Jurja Dobrile u Puli. http://www.unipu.hr/uploads/media/Razvojna_strategija2010-2015. pdf (datum pristupa 15. siječnja 2015).

UNIPU. 2018. Povijest Sveučilišta Jurja Dobrile u Puli. https://www.unipu.hr/o_sveucilistu/povijest (datum pristupa: 12. travnja 2018).

UNIRI (Sveučilište u Rijeci). 2004. Zapisnik sa 105. sjednice Senata, 23. rujna.

UNIRI. 2007. Sveučilište u Rijeci - Strategija 2007-2013. http://www.uniri.hr/files/staticki_dio/strategija/SVURI01-01Strategija.pdf (datum pristupa 15. siječnja 2015).

UNIRI. 2012. Uspješnost provedbe Bolonjskog procesa na Sveučilištu u Rijeci - Izvješće. https://www.biotech.uniri.hr/files/Dokumenti/UniRi_izvjesce_Bolonjski_ proces.pdf (datum pristupa 18. siječnja 2015).

UNIZD (Sveučilište u Zadru). 2011. Strategija Sveučilišta u Zadru 2011-2017. http:// www.unizd.hr/Portals/0/pdf/Strategija_2011_2017_2.pdf(datum pristupa 17. siječnja 2015).

UNIZD. 2018. O nama. http://www.unizd.hr/Onama/tabid/55/language/hr-HR/Default. aspx (datum pristupa: 12. travnja 2018).

UNIZG (Sveučilište u Zagrebu). 2002. Iskorak. http://www.unizg.hr/fileadmin/ rektorat/O_Sveucilistu/Dokumenti_javnost/Dokumenti/Strateski_dokumenti/iskorak2001/razvojna_strategija_svucilista_u_zagrebu.pdf (datum pristupa 18. rujna 2014).

UNIZG. 2013. Razvoj i preobrazba Sveučilišta u Zagrebu. http://www.unizg.hr/filead$\mathrm{min} /$ rektorat/O_Sveucilistu/Dokumenti_javnost/Dokumenti/Strateski_dokumenti/ RiP_SuZ_-_razrada_konacna.pdf (datum pristupa 14. siječnja 2015).

Uvalić, Radivoj. 1952. The Organization of Higher Education in Yugoslavia. United Nations Educational, Scientific and Cultural Organization. http://unesdoc.unesco.org/ images/0017/001790/179034eb.pdf (datum pristupa 8. rujna 2013).

Vukosav, Branimir. 2006. Hrvatskoj je potrebna cjelovita strategija razvoja visokog školstva. Zadarski list, 28. veljače, str. 17.

Zohlnhöfer, Reimut. 2009. How Politics Matter When Policies Change: Understanding Policy Change as a Political Problem. Journal of Comparative Policy Analysis, (11), 1: 97-115. 


\title{
Nikola Baketa \\ CHANGES IN QUALITY ASSURANCE POLICY \\ AT PUBLIC UNIVERSITIES IN CROATIA \\ FROM 2001 UNTIL 2013
}

\begin{abstract}
Summary
From the theoretical perspective of historical institutionalism and concept of policy change the author detects and analyzes the initiators of change and key conditions that enabled or prevented the change in quality assurance policy at public universities in Croatia from 2001 to 2013. The analysis includes seven public universities - the University of Zagreb, the University of Split, the University of Rijeka, the Josip Juraj Strossmayer University of Osijek, the University of Zadar, the University of Dubrovnik and the Juraj Dobrila University of Pula. Using qualitative methods (directed content analysis and semi-structured interviews) to follow the process of policy change, it has been established that the main motors of change are external. The main conclusion is that the institutional structure can be a prerequisite that enables actors to implement change, but that certain features of actors, such as their capacities, are necessary for policy change.
\end{abstract}

Keywords: Quality, University, Policy Change, Historical Institutionalism, Croatia

Nikola Baketa je poslijedoktorand na Institutu za društvena istraživanja u Zagrebu. Kontakt: Nikola Baketa, Institut za društvena istraživanja u Zagrebu, Amruševa 11/II, 10000 Zagreb. E-mail: baketa@idi.hr 